\title{
Assessing the impact of resolution and soil datasets on flash-flood modelling
}

\author{
Alexane Lovat ${ }^{1}$, Béatrice Vincendon ${ }^{2}$, and Véronique Ducrocq ${ }^{1}$ \\ ${ }^{1}$ CNRM, Université de Toulouse, Météo-France, CNRS, Toulouse, France \\ ${ }^{2}$ DCSC, Météo-France, Toulouse, France
}

Correspondence: Alexane Lovat (alexane.lovat@meteo.fr)

Received: 9 July 2018 - Discussion started: 31 July 2018

Revised: 11 February 2019 - Accepted: 16 March 2019 - Published: 2 April 2019

\begin{abstract}
The present study assesses the impacts of two grid resolutions and the descriptors of soil texture and land cover on flash-flood modelling at local and basin scales. The ISBATOP coupled system, which is dedicated to Mediterranean flash-flood simulations, is used with two grid-cell sizes (300 and $1000 \mathrm{~m}$ ), two soil texture datasets, and two land use databases to model 12 past flash-flood events in southeastern France. The skill of the hydrological simulations is assessed using conventional data (discharge measurements from operational networks) and proxy data such as post-event surveys and high-water marks. The results show significant differences between the experiments in terms of both the simulated river discharge and the spatial runoff, whether at the catchment scale or at the local scale. The spatial resolution has the largest impact on the hydrological simulations. In this study, it is also shown that the soil texture has a larger impact on the results than the land cover.
\end{abstract}

\section{Introduction}

Devastating flash floods triggered by heavy precipitation events occur in the Mediterranean coastal regions, primarily in autumn (Ricard et al., 2012). The mesoscale convective systems associated with these precipitating events and the geomorphologic characteristics of the region can lead to short hydrological response times ranging from a few minutes to a few hours. These floods represent a significant hazard to human safety and a threat to property and have caused at least 85 billion euros in damage since 1900 in the countries surrounding the Mediterranean Sea (Gaume et al., 2016). Accurate simulations and forecasts of the hydrologic behaviour of these catchments, such as the runoff produced during a precipitating event, are essential for identifying exposed areas, issuing effective warnings and guidance, and notifying at-risk populations. Nevertheless, the complex space-time features of Mediterranean precipitating systems make flash floods particularly difficult to model and forecast. Several hydrological models are devoted to this type of event. Such models are designed to properly simulate fast responding river discharge and the areas where runoff is produced. For floods or flash floods, the forecast ability depends not only on the spatial and temporal accuracy of the rainfall forcing (Van Steenbergen and Willems, 2014; Vivoni et al., 2007; Garambois et al., 2015) but also on the model description of the physical and hydrological characteristics of the watershed (Cotter et al., 2003; Marchi et al., 2010). Several authors have studied how to account for uncertainties associated with meteorological data, initial soil moisture, and hydrological model parameters. Zappa et al. (2011) have investigated the propagation and the superposition of these three sources of uncertainty in a hydrometeorological forecasting system for a catchment of the Swiss Alps. Meteorological data uncertainties have been addressed using high-resolution ensemble numerical weather predictions to issue probabilistic discharge forecasts (Ferraris et al., 2002; Vincendon et al., 2011; Hardy et al., 2016). Other methods have also been studied, such as the post-processing of deterministic quantitative precipitation forecasts (Vincendon et al., 2011) or the use of bias correction techniques (Zalachori et al., 2012) or multi-model numerical weather prediction (NWP) forecasts (McBride and Ebert, 2000). The coupling of meteorological ensemble prediction systems with hydrological ensemble systems has been notably studied in HEPEX (the Hy- 
drologic Ensemble Prediction Experiment; Schaake et al., 2007). The sensitivity of the hydrological models to the initial soil moisture (e.g. Silvestro and Rebora, 2014) and to hydrological parameters (e.g. Liu et al., 2012; Edouard et al., 2018) has also been extensively studied in the past. Based on such a sensitivity study, Edouard et al. (2018) designed an ensemble prediction system for flash-flood forecasting. In addition, hydrological modelling uncertainties arise from the soil and land descriptions. Elevation, land use, and soil texture datasets are available at various spatial resolutions and from various data providers. Many hydrological models are calibrated, and the value of the calibrated parameters may depend on such terrain descriptors. Several studies have investigated the impact of soil and land data and their resolution using various digital elevation model (DEM), land cover (Kamali et al., 2017; Yen et al., 2015; Sharifi and Kalin, 2010), and soil datasets (e.g. the Soil Survey Geographic database and the State Soil Geographic database; Kumar and Merwade, 2009; Chaplot, 2014; Cotter et al., 2003). The influence of the model resolution, which is strongly linked to the soil and land data resolution, has also been investigated (Vázquez et al., 2002; Egüen et al., 2012). Even if in general a higher resolution leads to more accurate simulations, there can be a critical level beyond which the model response is not necessarily improved (Hengl, 2006; Egüen et al., 2012). Land use and, in particular, preferential pathways can have a large impact on the catchment residence times and the time that the flood wave travels (Blöschl, 2001; Blöschl et al., 2007). Several studies have identified the most appropriate model structure in hydrological modelling while taking into account several landscape complexity levels (e.g. Flügel, 1995; Savenije, 2010; Gharari et al., 2014a, b). Gharari et al. (2014a) have used models of increasing complexity (the first represents the catchment in a lumped way, and the second distinguishes wetlands from the remainder, i.e. hillslopes and plateaus, and the third gives a complete representation of the wetlands, hillslopes, and plateaus). They showed that by allowing for more landscape-related process heterogeneity in a model (third model), the predictive power increases even without traditional calibration. The impact of the representation of the soil and land properties on flash-flood modelling remains poorly explored, even though these descriptors are expected to influence the timing of the flash-flood prediction and the spatial and temporal distribution of the runoff. Of the few studies dedicated to flash floods, Rozalis et al. (2010) used an uncalibrated hydrological model based on the SCS curve number method (SCS, 1964) to simulate the effect of land use changes and urban development on the flash-flood intensity over a Mediterranean watershed in Israel. Antonetti et al. (2016) explored recently the uncertainty of hydrological simulations due to different spatial representations of dominant runoff processes. They found that the simulations with the most complex automatic mapping approach are the closer to the reference map, while those without soil information differed considerably. Anquetin et al.

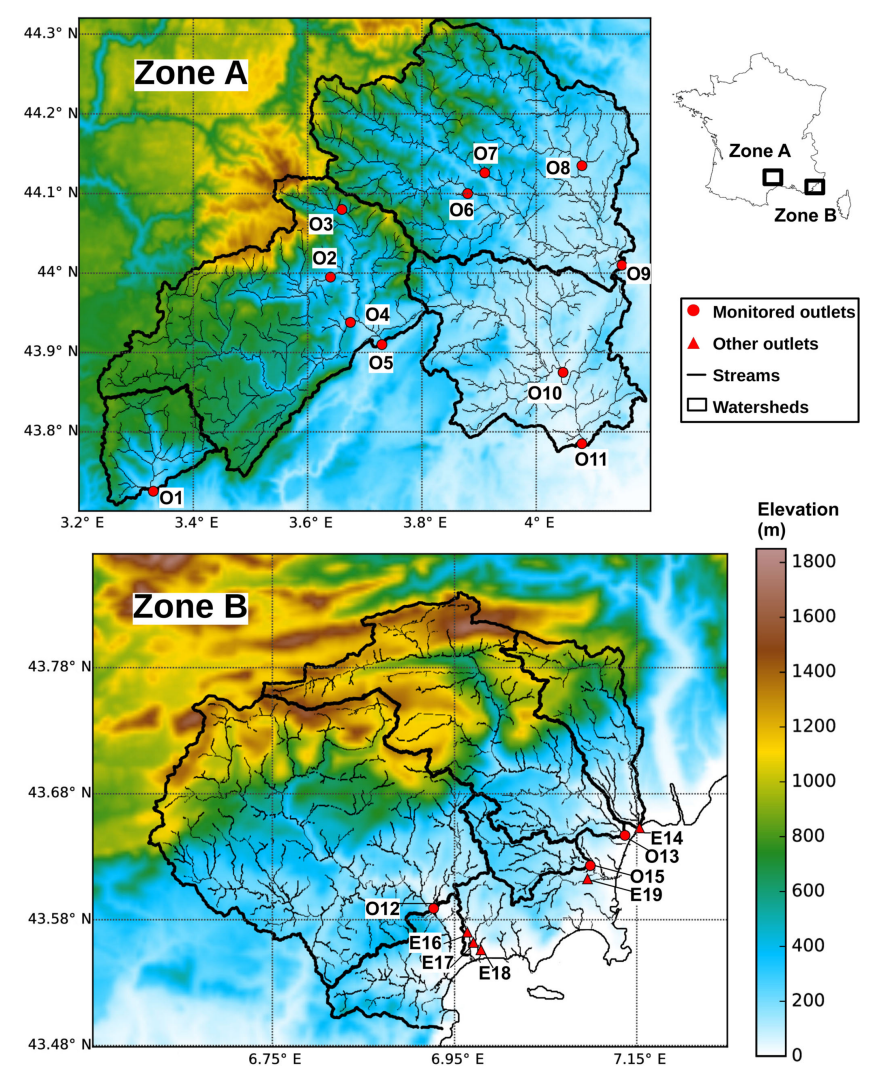

Figure 1. Location of the study areas, zones A and B, and boundaries of the main watersheds of both areas. The red markers correspond to the studied outlets. The circular outlets are monitored. Coordinates are in WGS84. The elevation was obtained from the SRTM dataset.

(2010) investigated the impact of the soil spatial variability on the simulated discharge for an extreme event in southern France. Their results identified two phases in the flood dynamics: the first one was primarily controlled by the soil properties, and the second one, after soil saturation, was controlled by the rainfall variability. If the soil properties are simplified in the hydrological model (catchments were described using only their major soil type), the resulting misestimation of the maximum storage capacity of the catchment leads to large errors in the flow simulation (Anquetin et al., 2010).

The present study investigates the impacts of the spatial resolution and terrain descriptors on flash-flood modelling using the ISBA-TOP hydrological model (Bouilloud et al., 2010; Vincendon et al., 2016), which is dedicated to Mediterranean flash-flood simulations. Two grid resolutions (300 and $1000 \mathrm{~m}$ ) and soil datasets are used with ISBA-TOP to simulate several past flash-flood events in southeastern France. Validating a flash-flood discharge and runoff simulation is extremely challenging. Indeed, the lack of surface runoff observations is a real impediment to evaluating a runoff simulation at the proper spatial scale. The streamflow measure- 
ments, which are classically used for discharge evaluations, are only sparsely available in this region. Many of the small watersheds affected by Mediterranean flash floods are ungauged. It is therefore necessary to seek other data indirectly related to the flash-flood magnitude that can provide valuable information on various aspects of the floods, such as the spatial expansion of the flood or its duration. Such proxy data include terrain in situ measurements, photos, and water marks. In the framework of the HyMeX (Hydrological cycle in the Mediterranean eXperiment) project (Drobinski et al., 2014; Ducrocq et al., 2014), post-event surveys have been conducted to document the characteristics and consequences of floods, even in ungauged catchments (Payrastre et al., 2015, 2016). A very recent database gathered floodrelated damage data since 2011 in the south of France at a fine scale (Saint-Martin et al., 2018). Javelle et al. (2014) demonstrated that these data provide valuable information for evaluating the simulated flood peak. New approaches are being explored to use flood-damage and runoff-impact data to evaluate the simulated runoff. For example, Vincendon et al. (2016) compared flooded area diagnoses with road-cut data, and Lagadec et al. (2016) used information from postevent surveys to evaluate a method to map the susceptibility to surface runoff from the impact of floods on a railway.

To investigate and rank the impacts of the spatial resolution and the terrain descriptors on flash-flood modelling, two spatial scales (catchment and local scales) are studied using conventional data as well as proxy data to assess the ISBATOP simulations, i.e. discharges measurements, post-event surveys, and high-water marks are used to evaluate the hydrological model outputs. This paper is organized as follows. Section 2 describes the study region, the hydrological system used, and its input datasets. The runoff model sensitivity to the grid resolution and the soil descriptors at different scales over several catchments are examined and discussed in Sect. 3. The conclusions are given in Sect. 4.

\section{Materials and methods}

\subsection{Case study}

The catchments of interest are located in southern France (Fig. 1). Two areas representative of rural and urban land use were chosen to investigate the impact of the soil properties on the performance of the hydrological model. The topography of both areas varies greatly from the sea level up to $1750 \mathrm{~m}$, with steep slopes and narrow valleys. The catchments have short response times, with rivers responding to rainfall events within approximately $2-7 \mathrm{~h}$ (see Table 1 ).

The rural zone " $A$ " consists of four catchments in the Cévennes region: the Lergue river at Lodève $\left(181 \mathrm{~km}^{2}\right)$, the Hérault river at Laroque $\left(918 \mathrm{~km}^{2}\right)$, the Gardon river at Ners $\left(1092 \mathrm{~km}^{2}\right)$ and the Vidourle river at Sommières $\left(621 \mathrm{~km}^{2}\right.$; Table 1). For the larger catchments, the simulations are also compared at the outlets of their sub-catchments. The Cévennes watersheds are prone to flash flooding, and their rivers are well monitored by the French flood forecasting service (SCHAPI). The Cévennes-Vivarais catchments have long been observed by the Cévennes-Vivarais Hydrometeorological Observatory (OHM-CV; Boudevillain et al., 2011). In addition, the FloodScale project (a multi-scale observation and modelling strategy for understanding and simulating flash floods; Braud et al., 2014), which contributes to the HyMeX international programme, performed enhanced observations for 4 years (2012-2015) in this region. A total of 11 recent flash-flood events occurring in zone A between 2014 and 2016 were considered in this study (Table 2). These were single or two-flow peak events and are representative of the variety of rainfall intensities and durations and the hydrological responses of the rivers encountered in the CévennesVivarais region.

The French Riviera was selected as the urban domain (Fig. 1) because it was affected by the last catastrophic flash-flood event in southern France on 3 October 2015 in the Cannes area. The urban zone "B" consists of four main catchments and two coastal areas. The catchments are the Siagne river at Pégomas $\left(515 \mathrm{~km}^{2}\right)$, the Loup river at Villeneuve-Loubet $\left(278 \mathrm{~km}^{2}\right)$, the Cagne river at Cagnes-surMer $\left(109 \mathrm{~km}^{2}\right)$, and the Brague river at Biot $\left(41 \mathrm{~km}^{2}\right)$ (see Table 1). Only a few watersheds are monitored in this region, and some basins are ungauged. In this study, eight discharge outlets were used; of these, three are monitored by SCHAPI. In the following, the outlets will be called $\mathrm{O}$ no. if they are operationally gauged by SCHAPI and E no. if their peak discharge values or water levels are estimated from post-event surveys or proxy data.

\subsection{The hydrological model ISBA-TOP}

The distributed hydrological model ISBA-TOP (Bouilloud et al., 2010; Vincendon et al., 2016) was designed to predict flash floods in small-sized to medium-sized Mediterranean basins. The ISBA-TOP system is a coupling between the land surface model ISBA (interaction surface-biosphereatmosphere; Noilhan and Planton, 1989) and TOPODYN (Pellarin et al., 2002). ISBA manages the soil water and energy budgets between the soil vegetation snow column and the atmosphere above natural land surfaces. TOPODYN is a variant of the hydrological model TOPMODEL (Beven and Kirkby, 1979), dedicated to flash-flood modelling in Mediterranean regions. It deals with the lateral redistribution of the soil moisture according to the topographical information and the spatial variability of the rainfall.

First, ISBA computes the water and energy fluxes within the soil column for all the grid meshes in its domain. From the resulting volumetric water content, the water-storage deficit is computed by TOPODYN for each watershed pixel with a resolution of $50 \mathrm{~m} \times 50 \mathrm{~m}$. The lateral distribution of the water along the watershed follows the principles of TOP- 
Table 1. Characteristics of the main studied catchments and outlets. Their locations are given in Fig. 1 from west to east within each catchment. The basin characteristic times, presented in Appendix A, are reported here. The names of the outlets of the main studied catchments are in bold.

\begin{tabular}{|c|c|c|c|c|c|c|}
\hline & River & Outlets & Name & Area $\left(\mathrm{km}^{2}\right)$ & tc $(\mathrm{h})$ & $\mathrm{tb}(\mathrm{h})$ \\
\hline \multirow[t]{11}{*}{ Zone A } & Lergue & Lodève & $\mathrm{O} 1$ & 181 & 3.2 & 1.9 \\
\hline & \multirow[t]{4}{*}{ Hérault } & Vigan (La Terrisse) & $\mathrm{O} 2$ & & & \\
\hline & & Valleraugue & $\mathrm{O} 3$ & & & \\
\hline & & Saint-Laurent-le-Minier & $\mathrm{O} 4$ & & & \\
\hline & & Laroque & O5 & 918 & 10.2 & 6.1 \\
\hline & \multirow[t]{4}{*}{ Gardon } & Saint-Jean-du-Gard & O6 & & & \\
\hline & & Mialet & $\mathrm{O} 7$ & & & \\
\hline & & Alès & O8 & & & \\
\hline & & Ners & O9 & 1092 & 8.8 & 5.3 \\
\hline & \multirow[t]{2}{*}{ Vidourle } & Vic-le-Fesq & $\mathrm{O} 10$ & & & \\
\hline & & Sommières & $\mathrm{O} 11$ & 621 & 8.8 & 5.3 \\
\hline \multirow[t]{8}{*}{ Zone B } & Siagne & Pégomas & $\mathrm{O} 12$ & 515 & 11.3 & 6.8 \\
\hline & Loup & Villeneuve-Loubet & $\mathrm{O} 13$ & 278 & 12 & 7.2 \\
\hline & Cagne & Cagnes-sur-Mer & E14 & 109 & 7.6 & 4.5 \\
\hline & Brague & Biot & $\mathrm{O} 15$ & 41 & 6 & 3.6 \\
\hline & \multirow[t]{4}{*}{ Eastern coastal zone } & Ranguin & E16 & & & \\
\hline & & Mougins & E17 & & & \\
\hline & & Cannes & E18 & & & \\
\hline & & Biot (Gorges) & E19 & & & \\
\hline
\end{tabular}

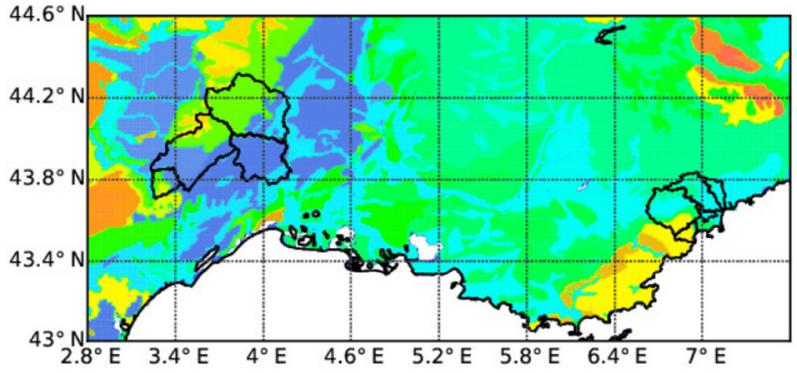

(a) SAND HWSD

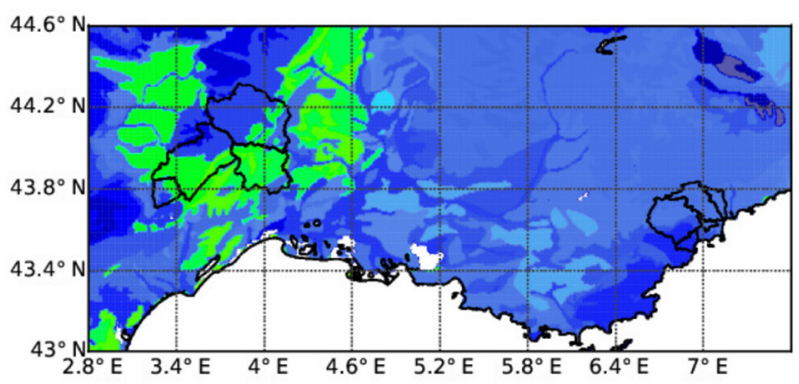

(c) CLAY HWSD

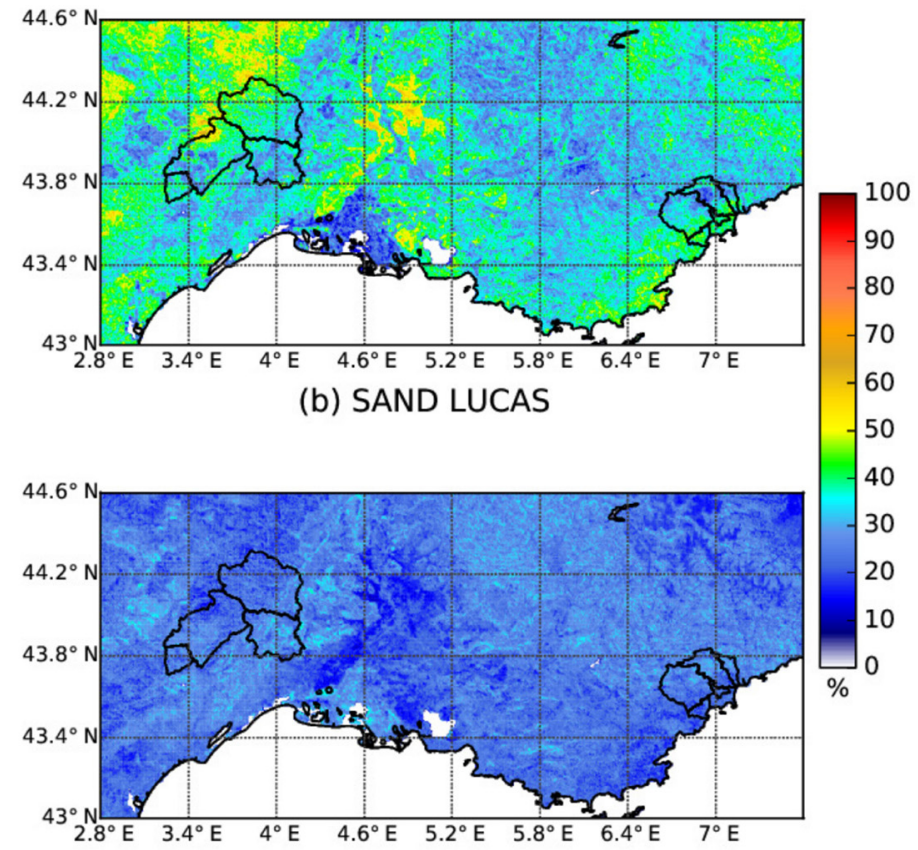

(d) CLAY LUCAS

Figure 2. Soil texture over southeastern France: fraction of sand from (a) HWSD and (b) LUCAS and fraction of clay from (c) HWSD and (d) LUCAS. The catchments of zones A and B are delineated in black. 
Table 2. Characteristics of the flash-flood events.

\begin{tabular}{llrr}
\hline $\begin{array}{l}\text { Starting day } \\
\text { of the } \\
\text { event }\end{array}$ & $\begin{array}{r}\text { Duration } \\
\text { (h) }\end{array}$ & $\begin{array}{r}\text { Maximum cumulative } \\
\text { rainfall observed } \\
(\mathrm{mm})\end{array}$ \\
\hline Zone A & $17 / 09 / 2014$ & 72 & 415.5 \\
& $11 / 10 / 2014$ & 73 & 105.9 \\
$28 / 11 / 2014$ & 49 & 228.9 \\
$12 / 09 / 2015$ & 73 & 390 \\
$28 / 10 / 2015$ & 73 & 179.2 \\
& $03 / 11 / 2015$ & 73 & 157.5 \\
& $05 / 04 / 2016$ & 49 & 111 \\
& $10 / 05 / 2016$ & 73 & 86.5 \\
$14 / 10 / 2016$ & 49 & 69.6 \\
& $21 / 11 / 2016$ & 73 & 287.5 \\
& $24 / 11 / 2016$ & 73 & 143.1 \\
\hline Zone B & $03 / 10 / 2015$ & 72 & 277.1 \\
\hline
\end{tabular}

MODEL using topographical indices. The new deficits and new soil moisture fields provide ISBA with new water contents. The pixels with a null deficit indicate the saturated contributing areas. From these areas, ISBA computes the subsurface runoff and deep drainage, which are routed to the river. The total discharges are then produced at the watershed outlets.

As part of the international HyMeX programme, the ISBA-TOP coupled system has been used for real-time prediction of discharge for four catchments in the CévennesVivarais region and the French Riviera during the first special observation period of HyMeX, from 5 September to 6 November 2012. Case studies have also been performed with ISBA-TOP for Italian (Nuissier et al., 2016) watersheds. ISBA-TOP is also currently used in real time by the National Institute of Meteorology and Hydrology (NIMH) of Bulgaria for operational flood forecasting for the Arda river basin (Artinyan et al., 2016).

\subsection{Soil characteristics}

\subsubsection{Soil texture}

The sensitivity to the soil texture (the proportion of clay, sand, and silt) in ISBA-TOP was assessed using two different datasets: the Harmonized World Soil Database (HWSD, version 1.2; Nachtergaele et al., 2012) and the Land use/cover area frame statistical survey (LUCAS) topsoil data (Ballabio et al., 2016).

The HWSD has global coverage at a resolution of $30 \operatorname{arcsec}$ (corresponding to approximately $1 \mathrm{~km}$ at the Equator). It combines soil information from several sources worldwide, including from the European Soil Database, various regional SOTER databases (SOTWIS Database), and the Soil Map of the World database (http://www.iiasa.ac.at/ Research/LUC/External-World-soil-database/HTML/, last

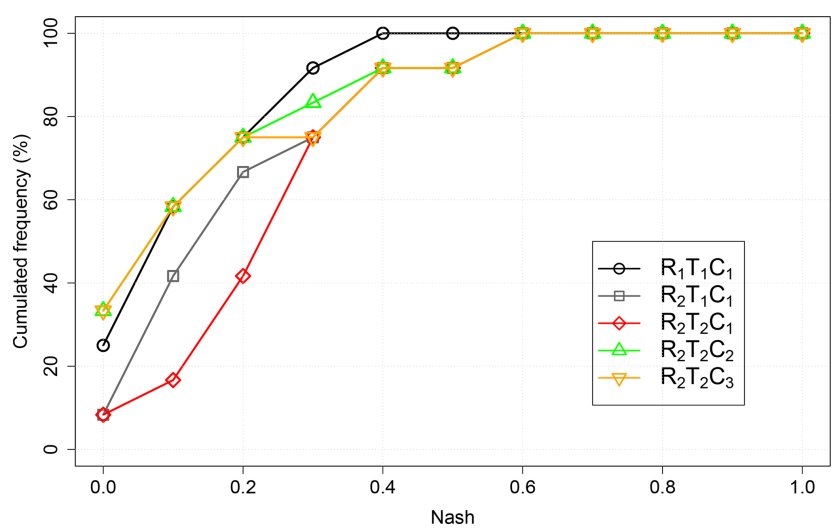

Figure 3. Cumulated frequency of the Nash values for each watershed in zone A for each experiment.

access: 28 March 2019). Tubiello et al. (2016) estimated the accuracy of the HWSD soil information to be approximately $75 \%$. The LUCAS dataset covers the European Union (EU) countries at a resolution of $500 \mathrm{~m}$. The soil properties were produced from the soil characteristics of the European Soil Database combined with the HWSD data. Ballabio et al. (2016) provided a map of the standard deviation (see their Fig. 7), which shows that, for zones A and B, the uncertainty is low, except for areas above $1000 \mathrm{~m}$ (corresponding to the upper part of the Siagne, Cagne, and Loup rivers in zone B), where the errors are large.

Figure 2 shows the clay and sand contents over southeastern France from the HWSD and LUCAS, respectively. The mean soil texture fractions per watershed are reported in Table 3. In the HWSD, the soil is mostly clay for the Vidourle and the southern part of the Hérault catchments (33\%-38\%), whereas sand is dominant for the Gardon and Lergue catchments (approximately $40 \%$ ). The spatial distribution of the soil texture is not so highly contrasting for LUCAS. In this second dataset, there is less clay over the Vidourle and Hérault catchments. For zone B, the proportions of sand in the HWSD are little higher than those of clay (38\% versus $24 \%$, respectively). For the southwestern part of zone $\mathrm{B}$, the proportion of clay is particularly low. LUCAS generally reports less sand than the HWSD for zone B.

Soil texture has an impact on simulated runoff through soil hydrodynamic parameters, which are determined by CH78 pedotransfer functions (Clapp and Hornberger, 1978) in ISBA-TOP. Edouard et al. (2018) investigated the impact of these parameters on runoff simulations.

\subsubsection{Land cover}

The land cover type (e.g. forest, grass, crop, rock, town, or sea) of each ISBA grid mesh is initialized with the ECOCLIMAP-II (Masson et al., 2003; Faroux et al., 2013) land ecosystem database at a resolution of $1 \mathrm{~km}$. Over Europe and the Mediterranean basin, ECOCLIMAP includes 
Table 3. Mean soil texture fractions per watershed from the HWSD and LUCAS topsoils and fraction of the land use types from ECOCLIMAP-II and ECO-SG.

\begin{tabular}{|c|c|c|c|c|c|c|c|c|c|}
\hline & & \multicolumn{4}{|c|}{ Zone A } & \multicolumn{4}{|c|}{ Zone B } \\
\hline & & $\begin{array}{r}\text { Lergue } \\
\text { O1 }\end{array}$ & $\begin{array}{r}\text { Hérault } \\
\text { O5 }\end{array}$ & $\begin{array}{r}\text { Gardon } \\
\text { O9 }\end{array}$ & $\begin{array}{r}\text { Vidourle } \\
\text { O11 }\end{array}$ & $\begin{array}{r}\text { Siagne } \\
\text { O12 }\end{array}$ & $\begin{array}{r}\text { Loup } \\
\text { O13 }\end{array}$ & $\begin{array}{r}\text { Cagne } \\
\text { E14 }\end{array}$ & $\begin{array}{r}\text { Brague } \\
\text { O15 }\end{array}$ \\
\hline \multirow{2}{*}{$\begin{array}{l}\text { Clay } \\
\%\end{array}$} & HWSD & 30.6 & 32.2 & 23.7 & 38.2 & 21.5 & 23.5 & 23.8 & 23.9 \\
\hline & LUCAS & 25.3 & 24.2 & 23.6 & 26.7 & 24.9 & 26.3 & 26.3 & 23.8 \\
\hline \multirow{2}{*}{$\begin{array}{l}\text { Sand } \\
\%\end{array}$} & HWSD & 38.2 & 35.6 & 40.4 & 26.9 & 40.7 & 37.6 & 36.6 & 36.1 \\
\hline & LUCAS & 33.9 & 36.8 & 38.5 & 32.3 & 33.5 & 31.3 & 31.6 & 39.1 \\
\hline \multirow{2}{*}{$\begin{array}{l}\text { Water } \\
\%\end{array}$} & ECOCLIMAP & - & - & - & - & - & - & 0.1 & - \\
\hline & ECO-SG & - & - & 0.1 & - & 0.5 & - & - & - \\
\hline \multirow{2}{*}{$\begin{array}{l}\text { Forests } \\
\%\end{array}$} & ECOCLIMAP & 50.5 & 48 & 55.6 & 40 & 48.1 & 37.6 & 23.3 & 32.1 \\
\hline & ECO-SG & 40.9 & 53.1 & 74.4 & 57.2 & 42.5 & 29.8 & 14.8 & 31.3 \\
\hline \multirow{2}{*}{$\begin{array}{l}\text { Shrubs-herbaceous- } \\
\text { grassland \% }\end{array}$} & ECOCLIMAP & 29.7 & 33.4 & 28 & 31.8 & 27.3 & 31 & 23 & 23.4 \\
\hline & ECO-SG & 31.4 & 25.3 & 6 & 7.5 & 22.7 & 35.5 & 35.7 & 4.6 \\
\hline \multirow{2}{*}{$\begin{array}{l}\text { Crops } \\
\%\end{array}$} & ECOCLIMAP & 10.1 & 9.6 & 6.7 & 10.3 & 7.5 & 12.5 & 12.6 & 4.3 \\
\hline & ECO-SG & 25.8 & 20.1 & 13.1 & 32.7 & 18.5 & 19.1 & 16.9 & 10.5 \\
\hline \multirow{2}{*}{$\begin{array}{l}\text { Urban-bare soil } \\
\%\end{array}$} & ECOCLIMAP & 9.7 & 9 & 9.7 & 17.9 & 17.1 & 18.9 & 41 & 40.2 \\
\hline & ECO-SG & 1.9 & 1.5 & 6.4 & 2.6 & 15.8 & 15.6 & 32.6 & 53.6 \\
\hline
\end{tabular}

273 landscape types, resulting from the merging of satellite data, i.e. the Corine Land Cover 2000 product over EU countries at a resolution of $100 \mathrm{~m}$, the Global Land Cover 2000 global database, and the SPOT-VEGETATION satellite data. In ISBA-TOP, the urban cover of ECOCLIMAP-II is considered to be a rocky cover to simulate the impervious surfaces of towns.

ECOCLIMAP Second Generation (ECOCLIMAP-SG; https://opensource.umr-cnrm.fr/projects/ecoclimap-sg/wiki/ Wiki, last access: 28 March 2019) is the latest version of ECOCLIMAP and is currently developed at a resolution of $300 \mathrm{~m}$. It is based on the European Space Agency (ESA) Climate Change Initiative (CCI) Land Cover product at a resolution of $300 \mathrm{~m}$ (version 1.6.1, 2016, epoch 2010, from 2008 to 2012), which gathered satellite MERIS and SPOT-VEGETATION data. To adapt the ESA CCI covers to the land cover types of ECOCLIMAP-SG, other data sources were compiled, such as the Shuttle Radar Topography Mission (SRTM) Water Body Data from the USGS, the Global Land Cover 2000, and the Corine Land Cover 2012. In this paper, the urban grid points of ECOCLIMAP-SG are considered to be either a fraction of bare soil, bare rock, temperate broadleaf deciduous and swamp areas (called ECO-SG), or bare rock (called ECO-SG-TownToRock).

In Table 3, the mean fractions of the land use types from ECOCLIMAP and ECO-SG are given. In ECOCLIMAP, a high percentage of every watershed in zone $\mathrm{A}$ is covered by forests $(40 \%-56 \%)$ and grass $(28 \%-34 \%)$. In general, ECO-SG presents even more forests (40\%-75\%) and less urban or bare soils in this area. For zone B, the land use
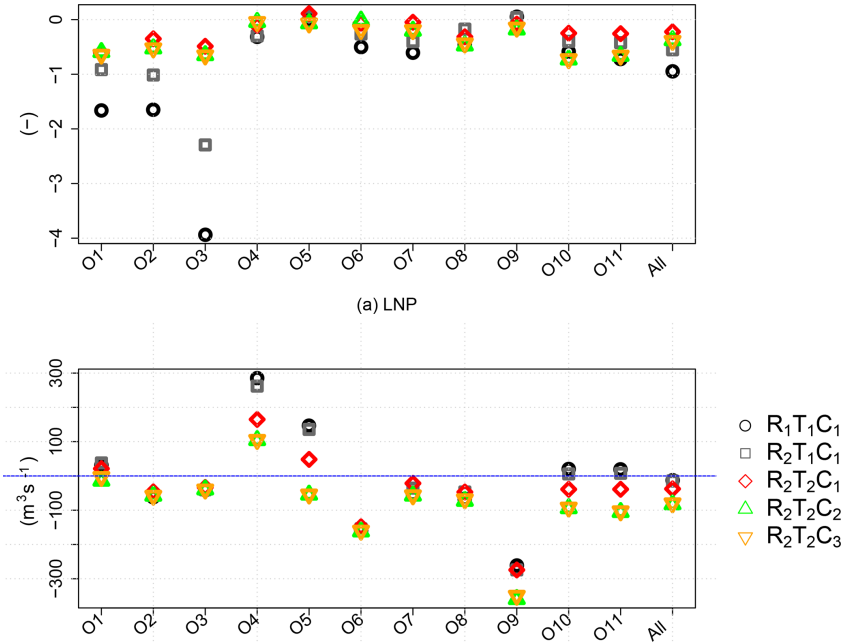

(b) Mean difference between simulated and observed peak values $\left(\mathrm{m}^{3} \mathrm{~s}^{-1}\right)$

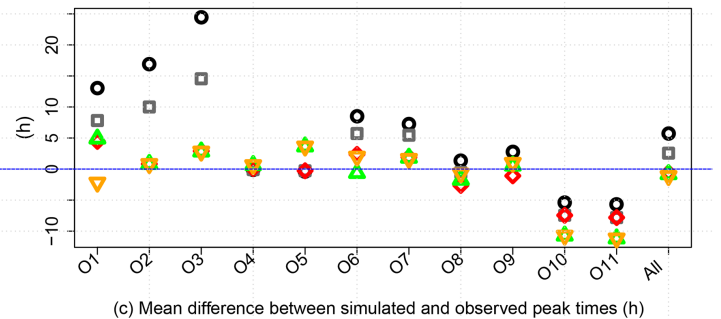

Figure 4. Scores for each watershed in zone A and all the outlets, for the $\mathrm{R}_{1} \mathrm{~T}_{1} \mathrm{C}_{1}-\mathrm{R}_{2} \mathrm{~T}_{2} \mathrm{C}_{3}$ experiments. 


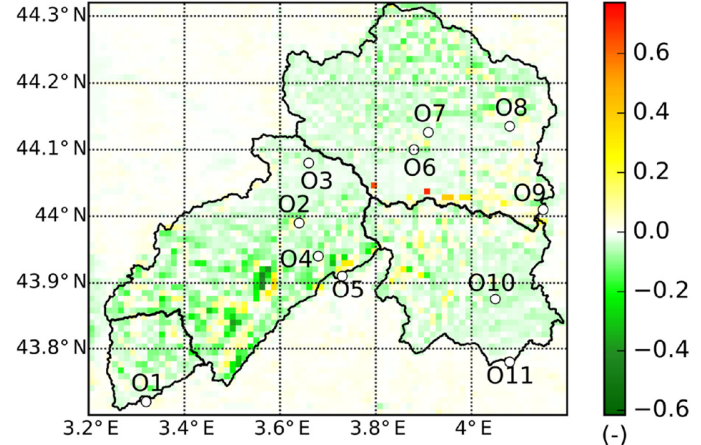

(a) $R_{1} T_{1} C_{1}-R_{2} T_{1} C_{1}$

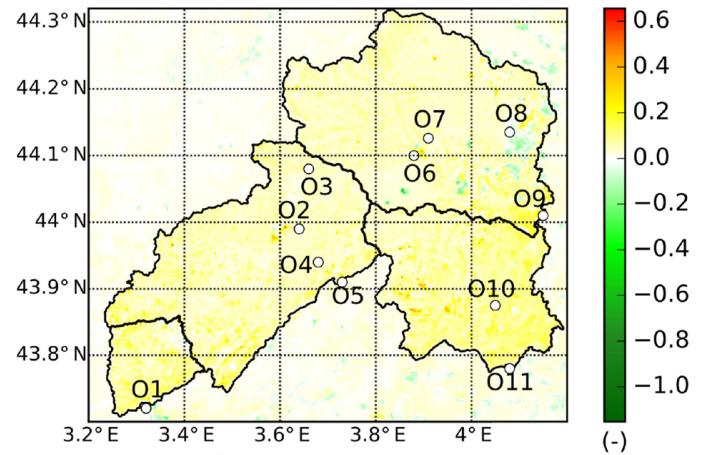

(c) $R_{2} T_{2} C_{1}-R_{2} T_{2} C_{2}$

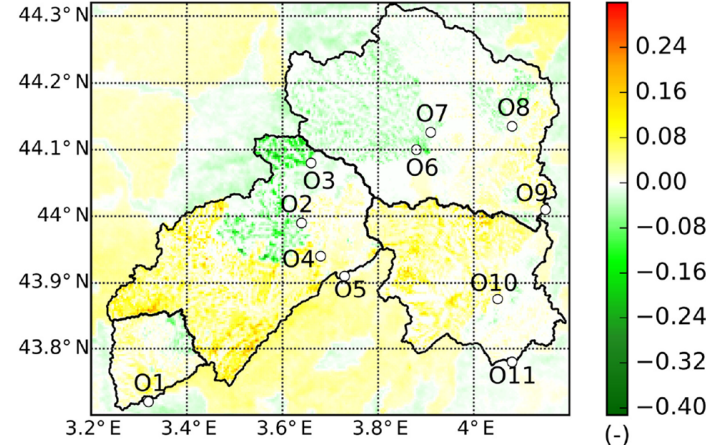

(b) $R_{2} T_{1} C_{1}-R_{2} T_{2} C_{1}$

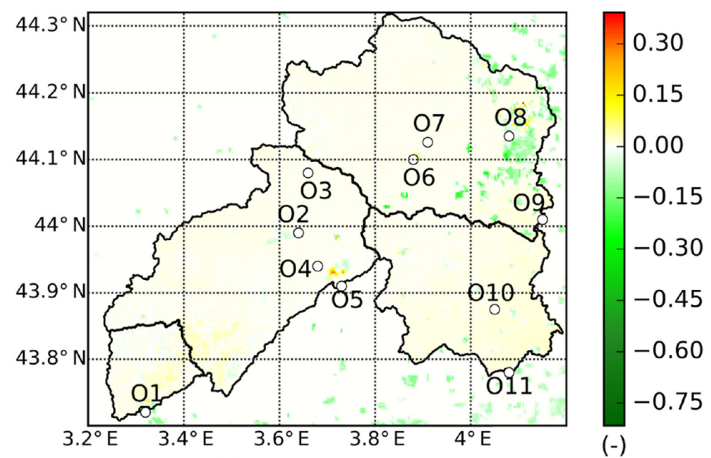

(d) $R_{2} T_{2} C_{2}-R_{2} T_{2} C_{3}$

Figure 5. Mean differences in the ratios of the runoff amounts to the rainfall amounts (without units) (a) between $R_{1} T_{1} C_{1}$ and $R_{2} T_{1} C_{1}$, (b) between $R_{2} T_{1} C_{1}$ and $R_{2} T_{2} C_{1}$, (c) between $R_{2} T_{2} C_{1}$ and $R_{2} T_{2} C_{2}$, and (d) between $R_{2} T_{2} C_{2}$ and $R_{2} T_{2} C_{3}$. Note that the range of the colour scale is not the same for the various panels; however, in red-yellow, the differences are always positive, and in green, they are always negative.

has a higher degree of contrast between the watersheds. In ECOCLIMAP, the soil is primarily covered by forests in the largest catchments of Siagne and Loup (37\%-48\%), whereas urban areas and towns are dominant in the Cagne and Brague catchments (approximately $40 \%$ ). For this zone, ECO-SG presents fewer forested areas than ECOCLIMAP but more crops. The proportions of urban or bare soils are of the same order for both datasets.

In ISBA-TOP, the land cover product influences both interception storage (through the leaf area index, vegetation height, and roughness length) and infiltration capacity (through the root depth), with resulting impacts on the simulated surface runoff amounts.

\subsection{Experiments}

Several experiments (see Table 4) were designed to assess the sensitivity of the simulated hydrological response to the horizontal resolution $(\mathrm{R})$, the soil texture $(\mathrm{T})$, and the land cover (C). ISBA was run with two different regular grids at resolutions of 300 and $1000 \mathrm{~m}$ to assess the impact of the horizontal resolution. These two resolutions were selected because the spatial resolution of meteorological forcing data used in this study is $1 \mathrm{~km}$ and because the new land ecosys-

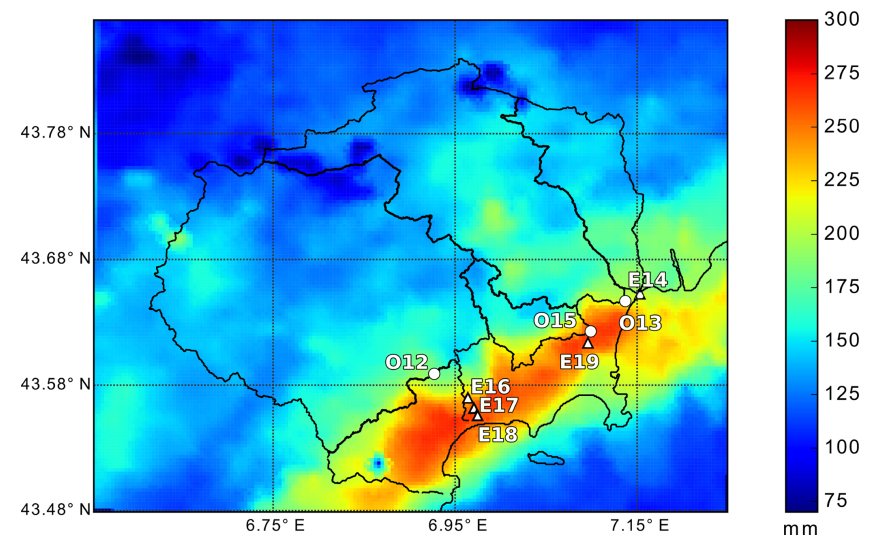

Figure 6. Cumulated rainfall over zone B during the October 2015 event for the Pégomas (O12), Villeneuve-Loubet (O13), Biot (O15), and Cannes (E18) locations.

tem database ECOCLIMAP Second Generation is produced at a $300 \mathrm{~m}$ resolution. The ISBA grid orography for each grid resolution was averaged from the SRTM $90 \mathrm{~m}$ digital elevation data (Fig. 1), which have a vertical accuracy of $\pm 16 \mathrm{~m}$ at the $90 \%$ confidence level (Jarvis et al., 2004). Note 
Table 4. Experimental parameters.

\begin{tabular}{lcc|cc|ccc}
\hline Simulations & \multicolumn{2}{c}{ Resolution (R) } & \multicolumn{2}{c}{ Texture (T) } & & \multicolumn{2}{c}{ Land cover (C) } \\
\cline { 2 - 7 } Names & $1000 \mathrm{~m}$ & $300 \mathrm{~m}$ & HWSD & LUCAS & ECOCLIMAP & ECO-SG & ECO-SG-TownToRock \\
\hline $\mathrm{R}_{1} \mathrm{~T}_{1} \mathrm{C}_{1}$ & $\times$ & & $\times$ & & $\times$ & & \\
$\mathrm{R}_{2} \mathrm{~T}_{1} \mathrm{C}_{1}$ & & $\times$ & $\times$ & & $\times$ & & \\
$\mathrm{R}_{2} \mathrm{~T}_{2} \mathrm{C}_{1}$ & & $\times$ & & $\times$ & $\times$ & & \\
$\mathrm{R}_{2} \mathrm{~T}_{2} \mathrm{C}_{2}$ & & $\times$ & & $\times$ & & $\times$ & \\
$\mathrm{R}_{2} \mathrm{~T}_{2} \mathrm{C}_{3}$ & & $\times$ & & $\times$ & & & \\
\hline
\end{tabular}

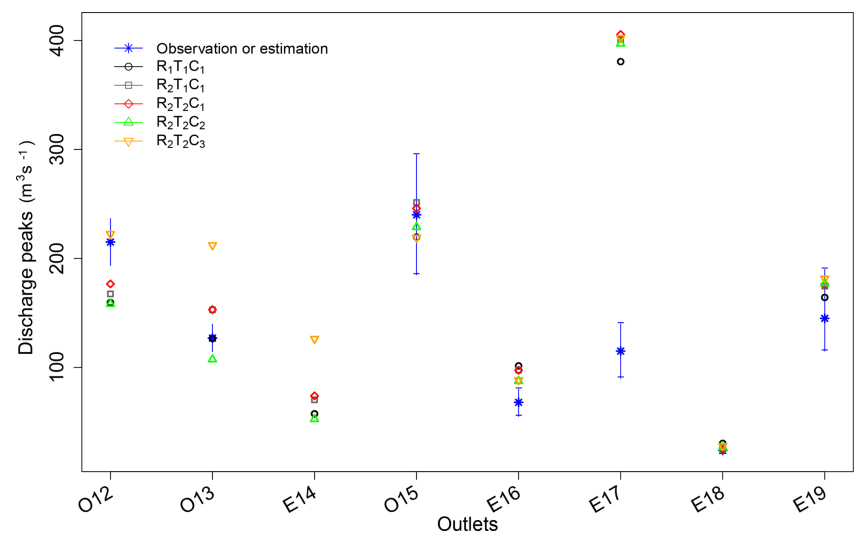

Figure 7. Discharge peaks $\left(\mathrm{m}^{3} \mathrm{~s}^{-1}\right)$ observed or estimated in blue and simulated by the $\mathrm{R}_{1} \mathrm{~T}_{1} \mathrm{C}_{1}-\mathrm{R}_{2} \mathrm{~T}_{2} \mathrm{C}_{3}$ experiments for each catchment for the October 2015 event. The error margins (blue segments) in the observed values (O no.) are approximately $10 \%$, and the error margins for the others (E no.) were estimated using post-event surveys. Only the damage was registered for E14 during this event; therefore, no estimate is available. For E18, the discharge values ranged between 20 and $28 \mathrm{~m}^{3} \mathrm{~s}^{-1}$.

that the watersheds in TOPODYN are described by a digital terrain model with a horizontal resolution of $50 \mathrm{~m}$ regardless of the ISBA grid resolution. The soil texture (from the HWSD or LUCAS) and land cover (from ECOCLIMAP-II or ECOCLIMAP-SG) were interpolated onto the ISBA grid. ISBA-TOP was run using five combinations of the available soil datasets. The first experiment, called $\left(\mathrm{R}_{1} \mathrm{~T}_{1} \mathrm{C}_{1}\right)$, corresponds to the conventional use of ISBA-TOP (e.g. Vincendon et al., 2016) at a resolution of $1000 \mathrm{~m}$ with the HWSD and ECOCLIMAP-II. The second experiment (called $\mathrm{R}_{2} \mathrm{~T}_{1} \mathrm{C}_{1}$ ) changed the resolution from $1000 \mathrm{~m}\left(\mathrm{R}_{1}\right)$ to $300 \mathrm{~m}\left(\mathrm{R}_{2}\right)$ to investigate the impact of the resolution. Three other experiments were performed at a resolution of $300 \mathrm{~m}$. The $\mathrm{R}_{2} \mathrm{~T}_{2} \mathrm{C}_{1}$ experiment evaluated the sensitivity to the soil texture by replacing the HWSD $\left(\mathrm{T}_{1}\right)$ with the LUCAS topsoil $\left(\mathrm{T}_{2}\right)$. Then, the sensitivity to the land cover was evaluated by replacing ECOCLIMAP-II with ECO-SG in the $\mathrm{R}_{2} \mathrm{~T}_{2} \mathrm{C}_{2}$ experiment. The last experiment, called $\mathrm{R}_{2} \mathrm{~T}_{2} \mathrm{C}_{3}$, tested the impact of the representation of the urban areas by replacing ECO-SG with ECO-SG-TownToRock.
For all the experiments, ISBA-TOP was driven by the hourly $1 \mathrm{~km}^{2}$ quantitative precipitation estimates (QPE) ANTILOPE, which merged observations from the Météo-France radar and the rain gauge network (Laurantin, 2008). The initial conditions (soil water and soil temperature) come from the Météo-France operational hydrometeorological system SAFRAN-ISBA-MODCOU (SIM; Habets et al., 2008), which provides the hourly soil water index (SWI) and soil temperature at a resolution of $8 \mathrm{~km}$ over France. The data were downscaled over the $1 \mathrm{~km}$ ISBA domain, using the nearest-grid-point interpolation method as in Edouard et al. (2018).

\section{Results}

\subsection{Analysis at the catchment scale}

\subsubsection{River discharges in zone A}

To compare the different experiments, several skill scores (described in Appendix B) were used. The Nash-Sutcliffe efficiency (NSE; Nash and Sutcliffe, 1970) was computed considering the catchments and sub-catchments together and separately for all the events in zone A (Fig. 3) to assess the overall simulated hydrograph. Streamflow measurements were provided by the French HYDRO data bank (http:// www.hydro.eaufrance.fr/, last access: 28 March 2019). The uncertainty in the discharge measurement in this data bank is approximately $\pm 10 \%$. In Fig. 3, the closer the points are to the bottom-right corner, the better the skill. The experiment $\mathrm{R}_{2} \mathrm{~T}_{2} \mathrm{C}_{1}$ has the best score, followed by $\mathrm{R}_{2} \mathrm{~T}_{1} \mathrm{C}_{1}$. The $\mathrm{R}_{1} \mathrm{~T}_{1} \mathrm{C}_{1}$ experiment generally performs worse than the others.

Figure 4a displays the LNP cost function (Roux et al., 2011). Compared with the Nash cost function, the LNP cost function grants more importance to the peak flow value and the timing. It consists of a linear combination of the Nash criterion and the error of the peak time and discharge (as defined by Lee and Singh, 1998). The differences between the simulated and observed peak values and times are also displayed in Fig. 4. As for NSE, these scores were computed over the entire data sample available for zone A using the 11 cases for all the outlets and monitored sub-watersheds taken 
separately and together. The accuracy of the discharges simulated with the different configurations depends on the catchments; however, some general tendencies can be extracted. The scores obtained for $\mathrm{R}_{2} \mathrm{~T}_{1} \mathrm{C}_{1}$ at a resolution of $300 \mathrm{~m}$ are generally better than those obtained for $\mathrm{R}_{1} \mathrm{~T}_{1} \mathrm{C}_{1}$ at a resolution of $1000 \mathrm{~m}$. The increase in the grid resolution appears to significantly improve the simulated peak time (see Fig. 4c). This might be due to the more detailed description of the river network and of the average slope over the watershed which influences the flow velocity (Dutta and Nakayama, 2009; Vázquez et al., 2002). The timing of the simulated peak is even better with the other experiments $\left(R_{2} T_{2} C_{1}-R_{2} T_{2} C_{3}\right)$. $\mathrm{R}_{2} \mathrm{~T}_{2} \mathrm{C}_{2}$ and $\mathrm{R}_{2} \mathrm{~T}_{2} \mathrm{C}_{3}$ give very similar results for every score of Figs. 3 and 4. In general, the best measures of the goodness of fit are obtained with $\mathrm{R}_{2} \mathrm{~T}_{2} \mathrm{C}_{1}$. The differences in the soil texture databases, which impact the water storage capacity and the ease of water to move through saturated soil, resulted in the most visible and beneficial changes in the simulated discharges. It was expected that fine-resolution input data (LUCAS and ECO-SG) would provide a better model performance for the hydrological simulations than coarser ones (HWSD and ECOCLIMAP); however, depending on the watershed $(\mathrm{O} 1, \mathrm{O} 10$, and $\mathrm{O} 11)$, the opposite can be seen in Fig. 4b. The scores show that the hydrological response is less sensitive to the land use data (compare $\mathrm{R}_{2} \mathrm{~T}_{2} \mathrm{C}_{1}$ and $\mathrm{R}_{2} \mathrm{~T}_{2} \mathrm{C}_{2}$ ) than to the soil texture data (compare $\mathrm{R}_{2} \mathrm{~T}_{1} \mathrm{C}_{1}$ and $\mathrm{R}_{2} \mathrm{~T}_{2} \mathrm{C}_{1}$ ); however, this result could be biased by the nearly homogeneous soils present in zone A (a large amount of forests and only a few cities; Table 3).

\subsubsection{Runoff over zone A}

To study the impact of the resolution, land use, and soil texture on the simulated runoff and to compare the simulations with each other, the runoff values computed at each ISBATOP grid point were cumulated over the entire event and divided by the associated amount of surface rain at the corresponding grid point during the event to take into account the spatial variability of the precipitation of each event. The differences in these ratios (the runoff amounts over the rainfall amounts) between $R_{2} T_{1} C_{1}$ and $R_{2} T_{2} C_{1}$, between $R_{2} T_{2} C_{1}$ and $R_{2} T_{2} C_{2}$, and between $R_{2} T_{2} C_{2}$ and $R_{2} T_{2} C_{3}$, respectively, were averaged over all the events (Fig. 5). The same processing was applied to compare $\mathrm{R}_{1} \mathrm{~T}_{1} \mathrm{C}_{1}$ with a resolution of $1000 \mathrm{~m}$ to $\mathrm{R}_{2} \mathrm{~T}_{1} \mathrm{C}_{1}$ with a resolution of $300 \mathrm{~m}$ after resampling at the same resolution using a nearest-neighbour interpolation. Enhancing the resolution results in an increase in the runoff production nearly everywhere (Fig. 5a). The few red-orange or dark green isolated spots (e.g. in the southeast of O6) may be explained by the large local height differences between the higher resolution model orography at $300 \mathrm{~m}$ and the smoother orography at $1000 \mathrm{~m}$. The change in the soil texture map (Fig. 5b) leads to high disparities in the spatial patterns of the surface runoff within the study domain. In general, $\mathrm{R}_{2} \mathrm{~T}_{1} \mathrm{C}_{1}$ produces more runoff than $\mathrm{R}_{2} \mathrm{~T}_{2} \mathrm{C}_{1}$, es-

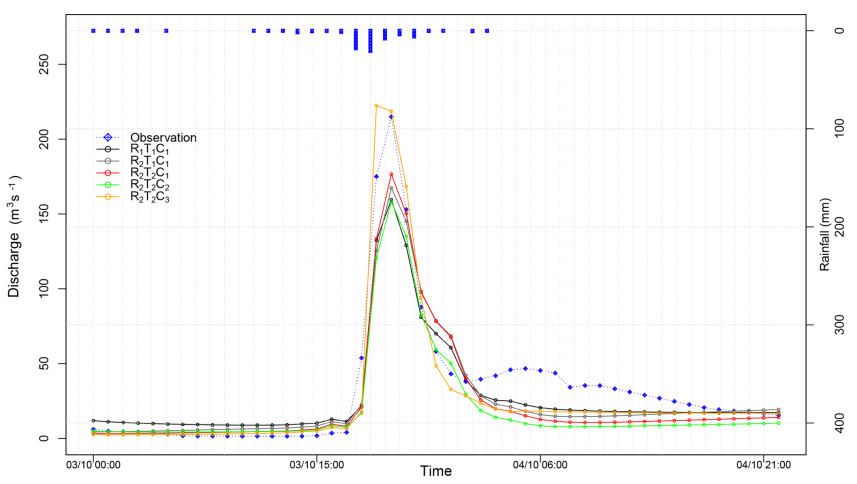

(a) Siagne River at Pégomas (O12)

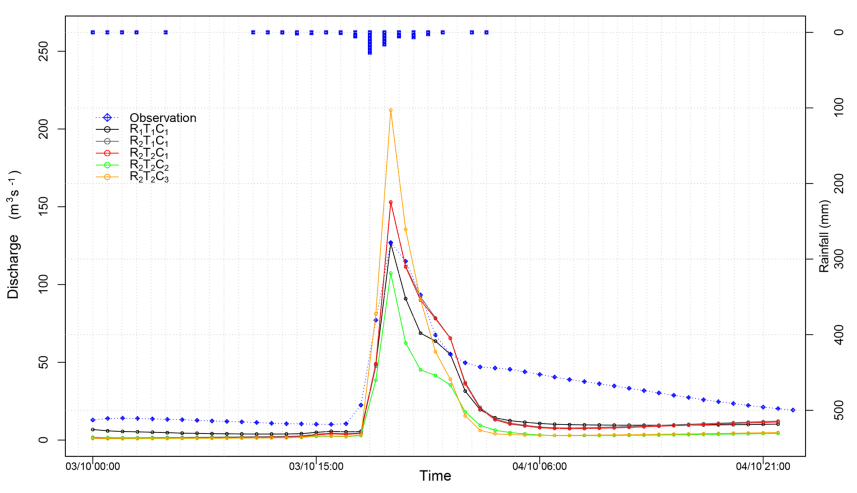

(b) Loup River at Villeneuve-Loubet (O13)

Figure 8. Discharge time series observed (blue curve) and simulated by ISBA-TOP in the five experiments $R_{1} T_{1} C_{1}-R_{2} T_{2} C_{3}$ for 3 October 2015 for (a) the Siagne river at Pégomas and (b) the Loup river at Villeneuve-Loubet. The reverse histogram represents the hourly rainfall averaged over the catchment.

pecially over the three more southerly watersheds where the clay fraction is higher with the HWSD (see O1, O5, and O11 in Table 3). This excess runoff is consistent with lower infiltration and drainage capacity associated with clay-rich soils. The areas with negative differences (green areas) often match areas with a minimum of clay in the HWSD (see Fig. 2). The change in land use (Fig. 5c) leads to the largest discrepancy between the different experiments at a resolution of $300 \mathrm{~m}$. Indeed, the mean differences in the ratios between the runoff and the rainfall range from -1.2 to 0.7 for $\mathrm{R}_{2} \mathrm{~T}_{2} \mathrm{C}_{1}-$ $R_{2} T_{2} C_{2}$, whereas for $R_{2} T_{1} C_{1}-R_{2} T_{2} C_{1}$, when changing the texture, that is, the range of the variation is between -0.4 and 0.3 . The simulations based on the land cover obtained from ECOCLIMAP-II show higher runoff amounts than ECO-SG (Fig. 5c), except south of the urbanized axis, O6-O8, where the difference is high. These amounts of surface runoff produced with $\mathrm{R}_{2} \mathrm{~T}_{2} \mathrm{C}_{2}$ in this catchment appear to be correlated to the amount of settlement areas and impervious areas in the catchment. The differences between $R_{2} T_{2} C_{2}$ and $R_{2} T_{2} C_{3}$ are less pronounced than those between $R_{2} T_{2} C_{1}$ and $R_{2} T_{2} C_{2}$, except on the eastern side of the $\mathrm{O} 8-\mathrm{O} 9$ axis and next to $\mathrm{O} 1$, 


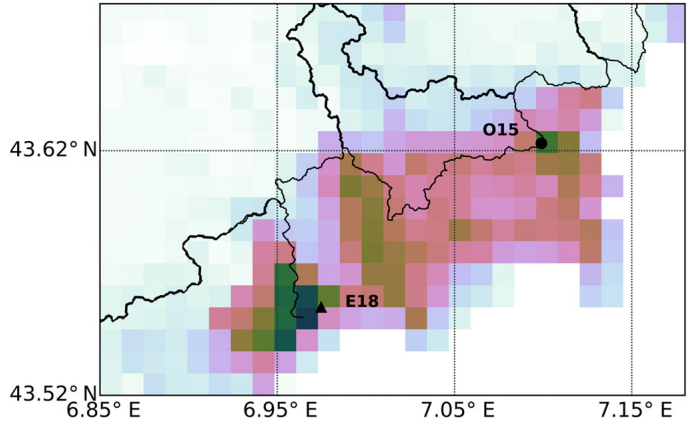

(a) $R_{1} T_{1} C_{1}$

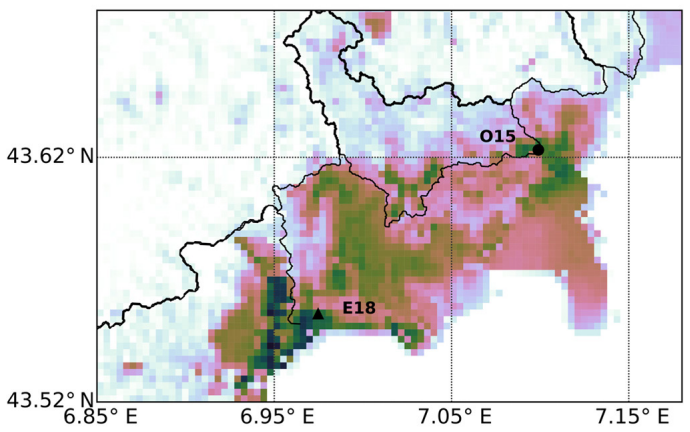

(c) $R_{2} T_{2} C_{1}$

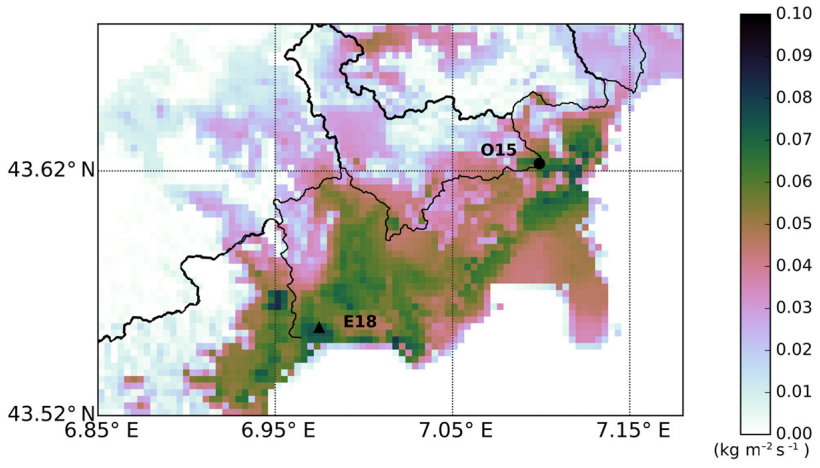

(e) $R_{2} T_{2} C_{3}$

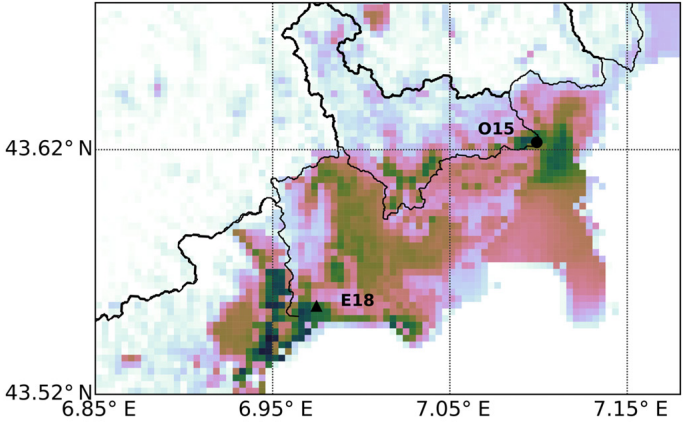

(b) $R_{2} T_{1} C_{1}$

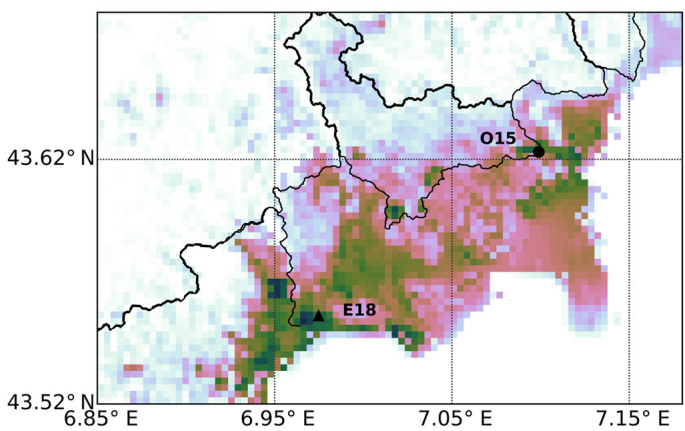

(d) $R_{2} T_{2} C_{2}$

Figure 9. Cumulated runoff for each experiment for the October 2015 event.

$\mathrm{O}$, and $\mathrm{O} 6$, where the pixels are more greenish than the surrounding pixels.

\subsubsection{Urbanized catchments of zone B}

To confirm the results obtained for zone A, the impact of various grid resolutions and soil datasets on simulations of the discharge and runoff were assessed for the more urbanized catchments of zone B. The percentages of urban cover and impervious soils in the catchments of zone $\mathrm{B}$ range from $16 \%$ to $54 \%$ (Table 3). The impacts were assessed for the catastrophic October 2015 event, which affected these watersheds. Extreme downpours and flash floods wreaked havoc over the French Riviera during this event. More than $270 \mathrm{~mm}$ of rain fell in the most affected area (Fig. 6).

For zone B, only the upward watersheds of Pégomas, Villeneuve-Loubet, and Biot are gauged. For the coastal area where the more severe precipitation occurred, the evaluation relies on estimated peak discharges from several post-event surveys conducted in the framework of the HyMeX project (Payrastre et al., 2016) and streamflow measurements from the French HYDRO database. The observed or estimated peak discharge for each watershed is displayed in Fig. 7 together with the peak discharge simulated by all five experiments. ISBA-TOP simulated flood peaks of the correct order of magnitude, except for the discharge point E17. The timing 


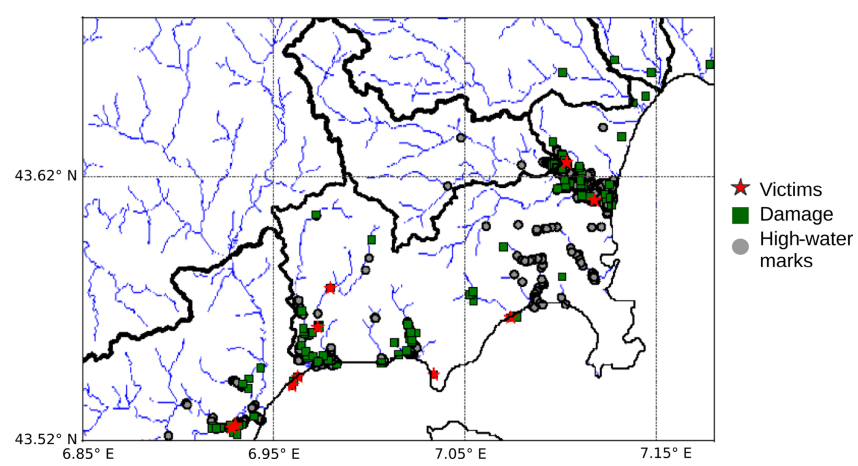

Figure 10. Impact map with the stream network. Locations of the victims are shown in red, damage is shown in green, and highwater marks are shown in grey. Fatalities and damage locations were provided by the multisource geodatabase DamaGIS (Saint-Martin et al., 2018).

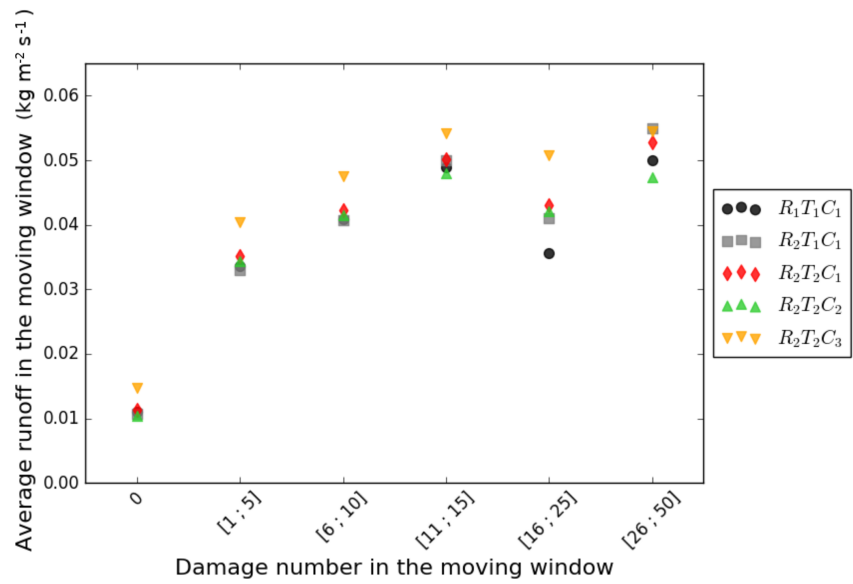

Figure 11. Average runoff as a function of the amount of damage encountered in the $1 \mathrm{~km}$ circular neighbourhood over all the domain of Fig. 9.

of the peak was also well simulated, according to Fig. 8. As in zone A, for most of the outlets, increasing the grid resolution of ISBA leads to peak values closer to the observations. However, contrary to zone $\mathrm{A}$, the discharge peak values simulated by $R_{2} T_{2} C_{2}$ and $R_{2} T_{2} C_{3}$ were significantly different for several watersheds in zone $\mathrm{B}$. Therefore, for these watersheds, replacing the mixture of bare soil, bare rock, and temperate broadleaf deciduous and swamp areas with only rock over the urban land use type patches had an impact.

The cumulated runoff for each experiment is displayed in Fig. 9. The spatial patterns of the surface runoff simulated by the different experiments are consistent with the surface accumulated rainfall (Figs. 6 compared to 9). Differences between the experiments appear primarily to the east and north of $\mathrm{O} 15$ as well as at the limit between the two coastal zones, west of E18. The areas of simulated high runoff match the observed impact zones (Fig. 10), which are located near the coast and close to $\mathrm{O} 15$.
The matching of the impacts and high runoff zones is assessed using a neighbouring approach for which a circular region, centred on each $300 \mathrm{~m}$ grid point, slides across all the domain of Fig. 9, counting the impacts of each category (victims, damage, and high-water marks) inside the circular region and the average runoff over the circular region. The radius of the circular area is set to $1 \mathrm{~km}$, allowing us to compare all the results at the coarser resolution of $\mathrm{R}_{1} \mathrm{~T}_{1} \mathrm{C}_{1}$ (i.e. $1 \mathrm{~km}$ ) without having too many sea grid-points in the circular regions with impacts along the coast. Figure 11 shows the average runoff as a function of the damage number. Clearly, the runoff is larger when impacts are recorded in the $1 \mathrm{~km}$ neighbourhood, in agreement with the visual comparison between Figs. 9 and 10. The average runoff increases with the impact number up to 10 instances of damage in the $1 \mathrm{~km}$ neighbourhood. $\mathrm{R}_{2} \mathrm{~T}_{2} \mathrm{C}_{3}$ (in yellow) produces on average more runoff than the other experiments. Figure 9 shows that significant runoff is produced over a larger area for $R_{2} T_{2} C_{3}$. In particular, over the urbanized areas south of the upward catchments, $\mathrm{R}_{2} \mathrm{~T}_{2} \mathrm{C}_{3}$ produces more runoff than the other experiments. The largest differences between the experiments are for the 16-25 instances of damage per circular area (Fig. 11). In this range, the $1 \mathrm{~km}$ resolution simulation $\left(\mathrm{R}_{1} \mathrm{~T}_{1} \mathrm{C}_{1}\right.$ in black) provides the lowest average value. The category of 16-25 instances of damage per circular region is mainly recorded next to $\mathrm{O} 15$, where $\mathrm{R}_{1} \mathrm{~T}_{1} \mathrm{C}_{1}$ produces less runoff (pink colour pixels in Fig. 9a).

\subsection{Analysis at the local scale}

A detailed analysis at the local scale was performed and is illustrated here for the 12 September 2015 event affected zone A. This event was remarkable in terms of its rainfall intensity (more than $220 \mathrm{~mm}$ in $3 \mathrm{~h}$ locally to the northeast of Lodève, called the $\mathrm{O} 1$ outlet) and river overflow in the Lergue basin, that is, the smallest catchment located southwest of zone A. Four grid points (called P1, P2, P3, and P4 in Fig. 12) in the city of Lodève were used to investigate differences between the experiments. At these points, the high-water levels were measured and archived on the collaborative web platform https://www. reperesdecrues.developpement-durable.gouv.fr/ (last access: 28 March 2019) (Piotte et al., 2016).

Figure 13 shows the cumulated runoff values between 03:00 UTC on 12 September 2015 and 08:00 UTC on 13 September 2015 simulated by the experiments $R_{1} T_{1} C_{1}-$ $\mathrm{R}_{2} \mathrm{~T}_{2} \mathrm{C}_{3}$ over the red square in Fig. 12. The spatial patterns of the surface runoff differ from one configuration to another and specifically with the change in the resolution (Fig. 13a and $b$ ). The distribution of runoff is obviously coarser in $\mathrm{R}_{1} \mathrm{~T}_{1} \mathrm{C}_{1}$, and the four points are in the same grid cell at a resolution of $1000 \mathrm{~m}$. The change in the land cover maps also has a significant influence (Figs. 13c and d). The higher value of the runoff is located near $\mathrm{P} 2$ for $\mathrm{R}_{2} \mathrm{~T}_{1} \mathrm{C}_{1}$ and $\mathrm{R}_{2} \mathrm{~T}_{2} \mathrm{C}_{1}$, whereas the runoff extends south of the Lergue watershed 

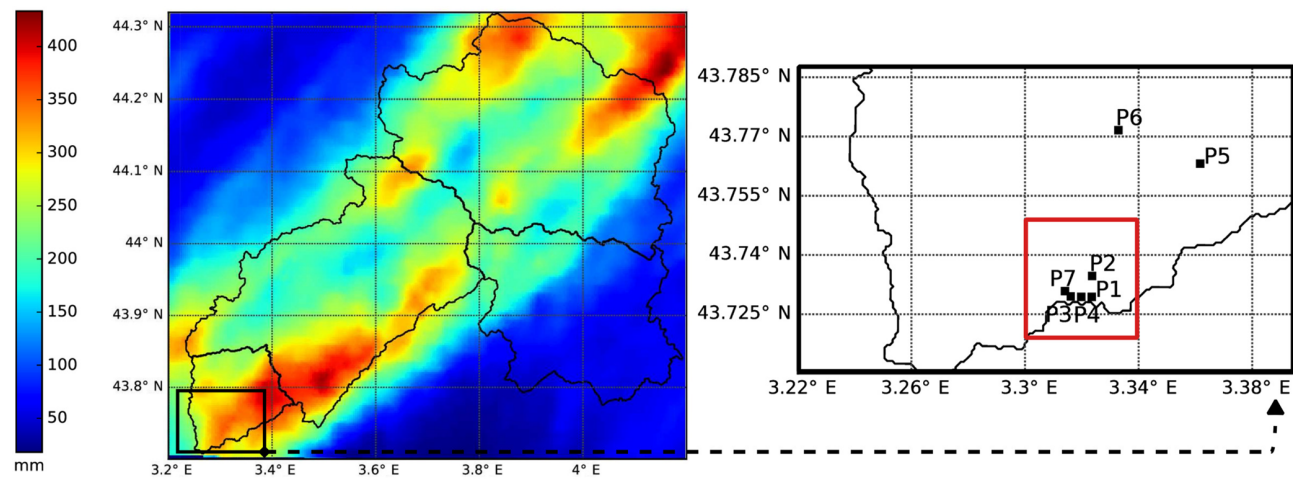

Figure 12. Cumulated rainfall during the 12 September 2015 event and the location of points P1-P7 (black squares) within the Lergue catchment in zone A.

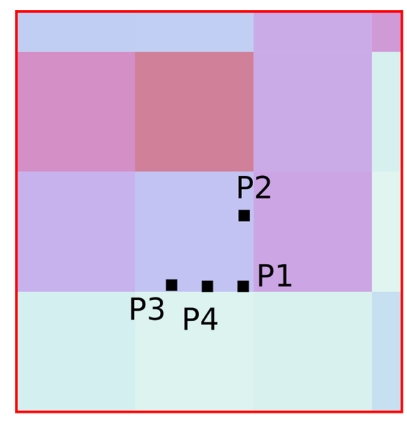

(a) $R_{1} T_{1} C_{1}$

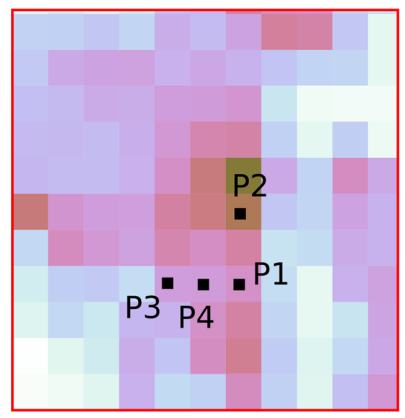

(d) $R_{2} T_{2} C_{2}$

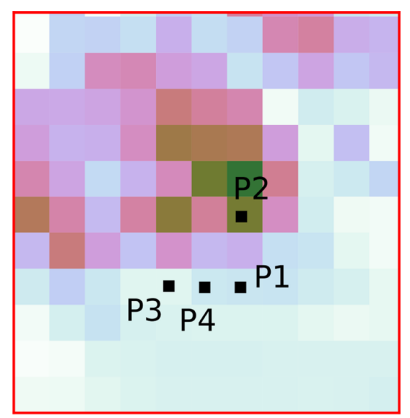

(b) $R_{2} T_{1} C_{1}$

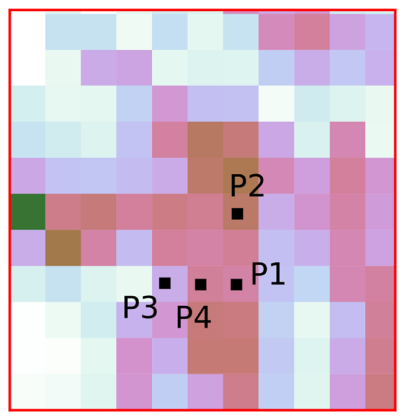

(e) $R_{2} T_{2} C_{3}$

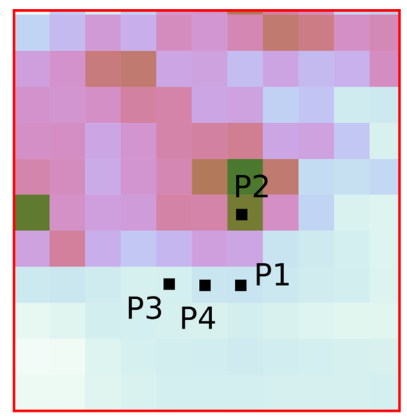

(c) $R_{2} T_{2} C_{1}$

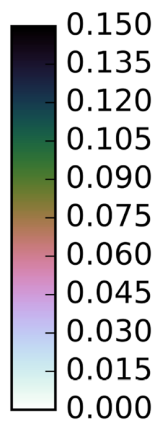

$\left(\mathrm{kg} \mathrm{m}^{-2} \mathrm{~s}^{-1}\right)$

Figure 13. Cumulated runoff during the September 2015 event for $R_{2} T_{1} C_{1}-R_{2} T_{2} C_{3}$ and the locations of points $P 1-P 4$.

for $R_{2} T_{2} C_{2}$ and $R_{2} T_{2} C_{3}$. The runoff is more intense for $\mathrm{R}_{2} \mathrm{~T}_{2} \mathrm{C}_{2}$ and $\mathrm{R}_{2} \mathrm{~T}_{2} \mathrm{C}_{3}$ than for $\mathrm{R}_{2} \mathrm{~T}_{1} \mathrm{C}_{1}$ and $\mathrm{R}_{2} \mathrm{~T}_{2} \mathrm{C}_{1}$, especially for points $\mathrm{P} 1, \mathrm{P} 3$, and $\mathrm{P} 4$ (see Fig. 13). The runoff time series shown in Fig. 14 leads to the same conclusion. The higher peak values for experiments $R_{2} T_{2} C_{2}$ and $R_{2} T_{2} C_{3}$ are also consistent with the measured high-water marks (Table 5) for the four points. ECO-SG and ECO-SG-TownToRock allow the observed runoff to be better represented locally. This might be due to the fact that, at $\mathrm{P} 1$ and $\mathrm{P} 4$, the land cover is primarily forest with ECOCLIMAP-II, whereas ECO-SG describes these points as being open and mid-rise, involving more impervious soils.
Table 5. High-water marks for points P1-P4 for the September 2015 event.

\begin{tabular}{lc}
\hline Point & Water level (m) \\
\hline P1 & 1.02 \\
P2 & 0.94 \\
P3 & 0.75 \\
P4 & 1.45 \\
\hline
\end{tabular}

For the same event and next to these points, the post-event flood peaks were estimated during the intensive post-event campaigns for HyMeX. These estimations concern the Breze 

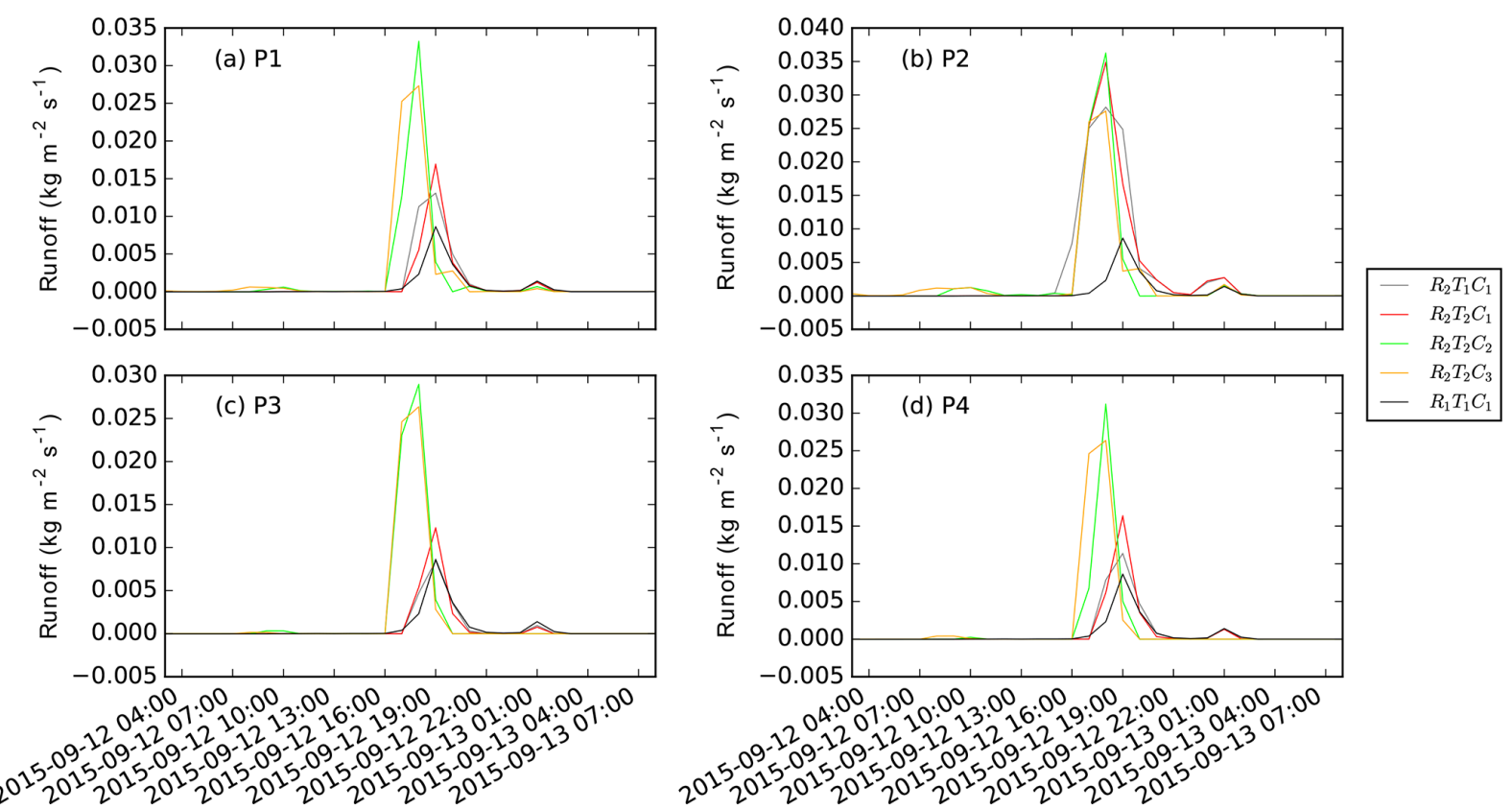

Figure 14. Runoff time series between 03:00 UTC on 12 September 2015 and 08:00 UTC on 13 September 2015 at (a) P1, (b) P2, (c) P3, and (d) P4.

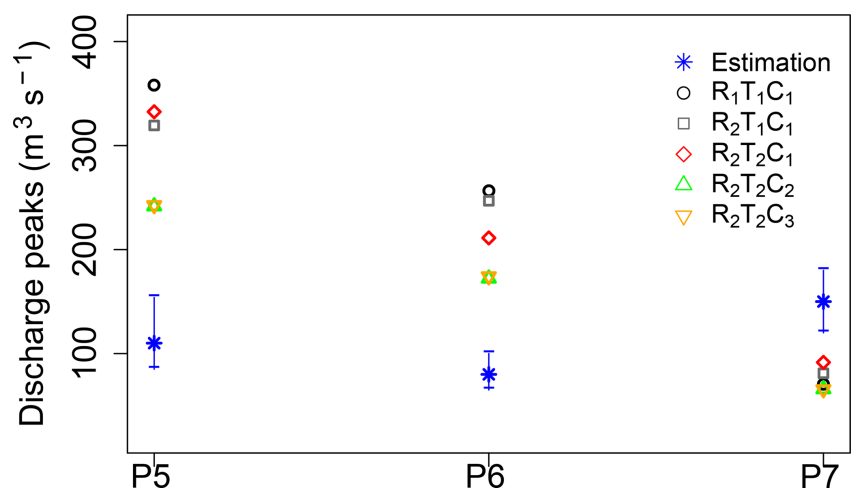

Figure 15. Estimated or simulated peak flows $\left(\mathrm{m}^{3} \mathrm{~s}^{-1}\right)$ during the September 2015 event. The error margins (blue segments) of the peak values were estimated using post-event surveys.

river at Saint-Étienne-de-Gourgas (P5), the Lergue river at Poujols (P6), and the Soulondre river at Lodève (P7). Their locations can be seen in the black square in Fig. 12. The estimated and simulated peak flows are shown in Fig. 15. $\mathrm{R}_{2} \mathrm{~T}_{2} \mathrm{C}_{2}$ and $\mathrm{R}_{2} \mathrm{~T}_{2} \mathrm{C}_{3}$ simulate more realistic values than $\mathrm{R}_{1} \mathrm{~T}_{1} \mathrm{C}_{1}, \mathrm{R}_{2} \mathrm{~T}_{1} \mathrm{C}_{1}$, and $\mathrm{R}_{2} \mathrm{~T}_{2} \mathrm{C}_{1}$ at $\mathrm{P} 5$ and $\mathrm{P} 6$ even though the values are overestimated.

\section{Conclusions}

The representation of the soil and land properties in hydrological models is crucial for flash-flood simulations in addition to other data concerning the rainfall and the initial state of the soil moisture. The impact of these terrain descriptors on predictions in terms of both the spatial and temporal distributions of the runoff has not been fully explored.

In this study, different sources of soil texture and land use data were used to describe two areas (a rural area and an urbanized area) in southeastern France using the ISBA-TOP system run at two different resolutions (300 and $1000 \mathrm{~m}$ ). The model performances, especially in terms of the runoff simulations, are difficult to assess. The results were analysed to rank the impacts of alternative physiographic maps for flash-flood modelling purposes at the catchment scale and at the local level. Discharge measurements, as well as proxy data such as post-event surveys and high-water marks, were used depending on their availability.

The main conclusions from this study are as follows.

- Changing the resolution of ISBA-TOP leads to differences in terms of the simulated river discharge and the spatial runoff. Higher resolution $(300 \mathrm{~m})$ simulations give more accurate results.

- The simulated discharge values are often more affected by differences in the soil texture databases than differences in the land use databases, especially in rural areas.

- No significant difference in the peak time was found when comparing the different $300 \mathrm{~m}$ experiments.

- Land cover and soil texture influence locally the processes in the catchments. Their spatial variability has an impact on the preferential flow paths, the flow velocities, and the water storage. The complexity of the inter- 
actions between processes at the catchment scale does not allow us to clearly conclude on how land cover and soil texture induce differences in simulated flows.

- Finally, in this study, the best results were obtained using SRTM data for orography, LUCAS data for soil texture, and ECOCLIMAP-II data for land cover at a resolution of $300 \mathrm{~m}$ (i.e. the $\mathrm{R}_{2} \mathrm{~T}_{2} \mathrm{C}_{1}$ experiment).

These conclusions need to be considered with caution because the sample of events and catchments was limited, especially for the urbanized area. Moreover, it would be interesting to compare these results with those that can be obtained using other hydrological models dedicated to flashflood modelling. For example, the higher sensitivity to soil texture than to land cover might depend on how the vegetation is treated in the model. Note that, for calibrated models, this impact might be "corrected" during the calibration procedure. Therefore, for a different dataset, the calibrated model needs to be recalibrated. In any case, for the future development of flash-flood modelling and forecasting, the impact of soil datasets should be taken into account in the uncertainty quantification, even though this impact is less significant than those associated with the rainfall and initial soil moisture. The lack of information with regard to flash floods in ungauged catchments may constitute a real barrier to the evaluation of the simulated hydrologic responses. Fortunately, data such as impact data from post-event surveys, "connected" measurements, and georeferenced data from social networks might be useful for enlarging the capacity of the model output assessments, especially during extreme events.

Data availability. Soil data can be obtained from the respective sources mentioned in Sect. 2.3. The Shuttle Radar Topographic Mission (SRTM) $90 \mathrm{~m}$ digital elevation data, originally produced by NASA, are available at the Consortium for Spatial Information of the Consultative Group for International Agricultural Research (CGIAR-CSI) geoportal (http://srtm.csi.cgiar.org/, last access: 28 March 2019). The Harmonized World Soil Database (HWSD, version 1.2) was provided by the Food and Agriculture Organization of the United Nations (FAO) and the International Institute for Applied Systems Analysis (IIASA). Precipitation rain gauges and initial conditions (soil water and soil temperature) data are provided by Météo-France and are available in the HyMeX database (https://doi.org/10.17616/R3M34X). Streamflow measurements are provided by the French HYDRO data bank (http: //www.hydro.eaufrance.fr/, last access: 28 March 2019). Proxy data come from the HyMeX database. The simulation data that support the findings of this study are available from the corresponding author on reasonable request. 


\section{Appendix A: Basin characteristic times}

The basin concentration time is estimated using the formulation of Bransby Williams (Almeida et al., 2015), which depends on the main channel length $L$, the catchment area $A$, and the average catchment slope $S: t_{\mathrm{c}}=0.605 \frac{L}{A^{0.1} S^{0.2}}$. The basin concentration time represents the time required for a single raindrop to travel from the hydraulically most distant point in the watershed to the outlet. The basin lag time is calculated using the formulation of the Soil Conservation Service (Maidment et al., 1993), which considers the ratio between the concentration time and lag time to be approximately 0.6. The lag time is the delay between the peak of the rain and the peak of the runoff.

\section{Appendix B: Scores}

\section{B1 NSE}

The Nash-Sutcliffe efficiency (NSE, Nash and Sutcliffe, 1970) is a normalized statistic that indicates if the simulated hydrological time series fits the observed one. Considering $N$ simulations hours, $Q_{i}^{S}$ is the value of the simulated hourly discharge at time $i, Q_{i}^{o}$ is the corresponding observation, and $\overline{Q^{\circ}}$ is the time-averaged observed discharge for the entire simulation. The NSE criterion tends to overrepresent large flows relative to other measurements due to the squared deviations: $\mathrm{NSE}=1-\frac{\sum_{i=1}^{N}\left(Q_{i}^{s}-Q_{i}^{o}\right)^{2}}{\sum_{i=1}^{N}\left(Q_{i}^{o}-\overline{Q^{o}}\right)^{2}}$.

\section{B2 LNP}

In the LNP cost function (Roux et al., 2011), $\mathrm{N}$ is the number of simulation hours, $Q_{p}^{s}$ and $Q_{p}^{o}$ are the simulated and observed peak discharges, respectively, $T_{p}^{s}$ and $T_{p}^{o}$ are the simulated and observed times to the peak, respectively, and $T_{c}^{o}$ is the concentration time of the catchment (see Sect. 2.1): $\mathrm{LNP}=\frac{1}{3} \mathrm{NSE}+\frac{1}{3}\left(1-\frac{\left|Q_{p}^{s}-Q_{p}^{o}\right|}{Q_{p}^{o}}\right)+\frac{1}{3}\left(1-\frac{\left|T_{p}^{s}-T_{p}^{o}\right|}{T_{c}^{o}}\right)$. 
Author contributions. AL performed the computational work. BV and VD supervised this work. All co-authors collaborated, interpreted the results, wrote the paper and replied to the comments from the reviewers.

Competing interests. The authors declare that they have no conflict of interest.

Special issue statement. This article is part of the special issue "Hydrological cycle in the Mediterranean (ACP/AMT/GMD/HESS/NHESS/OS inter-journal SI)". It is not associated with a conference.

Acknowledgements. This research was performed in the framework of the HyMeX programme (MISTRALS grants) and is a contribution to the French project PICS (ANR - 17 - CE03 - 0011). The authors would like to express their gratitude for access to useful data and discussions about ECOCLIMAP with Stéphanie Faroux (CNRM).

Review statement. This paper was edited by Giuseppe Tito Aronica and reviewed by Massimiliano Zappa and Renata Romanowicz.

\section{References}

Almeida, I., Kaufmann Almeida, A., Ayach Anache, J., Steffen, J., and Alves Sobrinho, T.: Estimation on Time of Concentration of Overland Flow in Watersheds: A Review, Geociencias, 33, 661671, 2015.

Anquetin, S., Braud, I., Vannier, O., Viallet, P., Boudevillain, B., Creutin, J.-D., and Manus, C.: Sensitivity of the hydrological response to the variability of rainfall fields and soils for the Gard 2002 flash-flood event, J. Hydrol., 394, 134-147, 2010.

Antonetti, M., Buss, R., Scherrer, S., Margreth, M., and Zappa, M.: Mapping dominant runoff processes: an evaluation of different approaches using similarity measures and synthetic runoff simulations, Hydrol. Earth Syst. Sci., 20, 2929-2945, https://doi.org/10.5194/hess-20-2929-2016, 2016.

Artinyan, E., Vincendon, B., Kroumova, K., Nedkov, N., Tsarev, P., Balabanova, S., and Koshinchanov, G.: Flood forecasting and alert system for Arda River basin, J. Hydrol., 541, 457-470, 2016.

Ballabio, C., Panagos, P., and Monatanarella, L.: Mapping topsoil physical properties at European scale using the LUCAS database, Geoderma, 261, 110-123, 2016.

Beven, K. and Kirkby, M. J.: A physically based, variable contributing area model of basin hydrology/Un modèle à base physique de zone d'appel variable de l'hydrologie du bassin versant, Hydrolog. Sci. J., 24, 43-69, 1979.

Blöschl, G.: Scaling in hydrology, Hydrol. Process., 15, 709-711, 2001.

Blöschl, G., Ardoin-Bardin, S., Bonell, M., Dorninger, M., Goodrich, D., Gutknecht, D., Matamoros, D., Merz, B., Shand,
P., and Szolgay, J.: At what scales do climate variability and land cover change impact on flooding and low flows?, Hydrol. Process., 21, 1241-1247, 2007.

Boudevillain, B., Delrieu, G., Galabertier, B., Bonnifait, L., Bouilloud, L., Kirstetter, P.-E., and Mosini, M.-L.: The Cévennes-Vivarais Mediterranean Hydrometeorological Observatory database, Water Resour. Res., 47 W07701, https://doi.org/10.1029/2010WR010353, 2011.

Bouilloud, L., Chancibault, K., Vincendon, B., Ducrocq, V., Habets, F., Saulnier, G.-M., Anquetin, S., Martin, E., and Noilhan, J.: Coupling the ISBA land surface model and the TOPMODEL hydrological model for Mediterranean flash-flood forecasting: description, calibration, and validation, J. Hydrometeorol., 11, 315-333, 2010.

Braud, I., Ayral, P.-A., Bouvier, C., Branger, F., Delrieu, G., Le Coz, J., Nord, G., Vandervaere, J.-P., Anquetin, S., Adamovic, M., Andrieu, J., Batiot, C., Boudevillain, B., Brunet, P., Carreau, J., Confoland, A., Didon-Lescot, J.-F., Domergue, J.-M., Douvinet, J., Dramais, G., Freydier, R., Gérard, S., Huza, J., Leblois, E., Le Bourgeois, O., Le Boursicaud, R., Marchand, P., Martin, P., Nottale, L., Patris, N., Renard, B., Seidel, J.-L., Taupin, J.-D., Vannier, O., Vincendon, B., and Wijbrans, A.: Multi-scale hydrometeorological observation and modelling for flash flood understanding, Hydrol. Earth Syst. Sci., 18, 3733 3761, https://doi.org/10.5194/hess-18-3733-2014, 2014.

Chaplot, V.: Impact of spatial input data resolution on hydrological and erosion modeling: Recommendations from a global assessment, Phys. Chem. Earth Pt. A/B/C, 67, 23-35, 2014.

Clapp, R. B. and Hornberger, G. M.: Empirical equations for some soil hydraulic properties, Water Resour. Res., 14, 601-604, 1978

Cotter, A. S., Chaubey, I., Costello, T. A., Soerens, T. S., and Nelson, M. A.: Water quality model output uncertainty as affected by spatial resolution of input data, J. Am. Water Resour. As., 39, 977-986, 2003.

Drobinski, P., Ducrocq, V., Alpert, P., Anagnostou, E., Béranger K., Borga, M., Braud, I., Chanzy, A., Davolio, S., Delrieu, G., Estournel, C., Boubrahmi, N., Filali, Font, J., Grubišić, V., Gualdi, S., Homar, V., Ivančan-Picek, B., Kottmeier, C., Kotroni, V., Lagouvardos, K., Lionello, P., Llasat, M. C., Ludwig, W., Lutoff, C., Mariotti, A., Richard, E., Romero, R., Rotunno, R., Roussot, O., Ruin, I., Somot, S., Taupier-Letage, I., Tintore, J., Uijlenhoet, R., and Wernli, H.: HyMeX: A 10-year multidisciplinary program on the Mediterranean water cycle, B. Am. Meteorol. Soc., 95, 1063-1082, 2014.

Ducrocq, V., Braud, I., Davolio, S., Ferretti, R., Flamant, C., Jansa, A., Kalthoff, N., Richard, E., Taupier-Letage, I., Ayral, P.-A., Belamari, S., Berne, A., Borga, M., Boudevillain, B., Bock, O., Boichard, J.-L., Bouin, M.-N., Bousquet, O., Bouvier, C., and Chiggiato, J.: HyMeX-SOP1: The field campaign dedicated to heavy precipitation and flash flooding in the northwestern Mediterranean, B. Am. Meteorol. Soc., 95, 1083-1100, 2014.

Dutta, D. and Nakayama, K.: Effects of spatial grid resolution on river flow and surface inundation simulation by physically based distributed modelling approach, Hydrol. Process., 23, 534-545, 2009.

Edouard, S., Vincendon, B., and Ducrocq, V.: Ensemble-based flash-flood modelling: Taking into account hydrodynamic parameters and initial soil moisture uncertainties, J. Hydrol., 560, 480-494, 2018. 
Egüen, M., Aguilar, C., Herrero, J., Millares, A., and Polo, M. J.: On the influence of cell size in physically-based distributed hydrological modelling to assess extreme values in water resource planning, Nat. Hazards Earth Syst. Sci., 12, 1573-1582, https://doi.org/10.5194/nhess-12-1573-2012, 2012.

Faroux, S., Kaptué Tchuenté, A. T., Roujean, J.-L., Masson, V., Martin, E., and Le Moigne, P.: ECOCLIMAP-II/Europe: a twofold database of ecosystems and surface parameters at $1 \mathrm{~km}$ resolution based on satellite information for use in land surface, meteorological and climate models, Geosci. Model Dev., 6, 563582, https://doi.org/10.5194/gmd-6-563-2013, 2013.

Ferraris, L., Rudari, R., and Siccardi, F.: The uncertainty in the prediction of flash floods in the northern Mediterranean environment, J. Hydrometeorol., 3, 714-727, 2002.

Flügel, W.-A.: Delineating hydrological response units by geographical information system analyses for regional hydrological modelling using PRMS/MMS in the drainage basin of the River Bröl, Germany, Hydrol. Process., 9, 423-436, 1995.

Garambois, P.-A., Roux, H., Larnier, K., Labat, D., and Dartus, D.: Parameter regionalization for a process-oriented distributed model dedicated to flash floods, J. Hydrol., 525, 383-399, 2015.

Gaume, E., Borga, M., Llassat, M. C., Maouche, S., Lang, M., and Diakakis, M.: Mediterranean extreme floods and flash floods, (Sub-chapter 1.3.4), Allenvi, The Mediterranean Region under Climate Change, A Scientific Update, Coll. Synthéses, IRD Editions, 133-144, 2016.

Gharari, S., Hrachowitz, M., Fenicia, F., Gao, H., and Savenije, H. H. G.: Using expert knowledge to increase realism in environmental system models can dramatically reduce the need for calibration, Hydrol. Earth Syst. Sci., 18, 4839-4859, https://doi.org/10.5194/hess-18-4839-2014, 2014a.

Gharari, S., Shafiei, M., Hrachowitz, M., Kumar, R., Fenicia, F., Gupta, H. V., and Savenije, H. H. G.: A constraintbased search algorithm for parameter identification of environmental models, Hydrol. Earth Syst. Sci., 18, 4861-4870, https://doi.org/10.5194/hess-18-4861-2014, 2014.b.

Habets, F., Boone, A., Champeaux, J.-L., Etchevers, P., Franchisteguy, L., Leblois, E., Ledoux, E., Le Moigne, P., Martin, E., Morel, S., Noilhan, J., Quintana-Segui, P., Rousset-Regimbeau, F., and Viennot, P.: The SAFRAN-ISBA-MODCOU hydrometeorological model applied over France, J. Geophys. Res.-Atmos., American Geophysical Union, 113, 18 pp., 2008.

Hardy, J., Gourley, J. J., Kirstetter, P.-E., Hong, Y., Kong, F., and Flamig, Z. L.: A method for probabilistic flash flood forecasting, J. Hydrol., 541, 480-494, 2016.

Hengl, T.: Finding the right pixel size, Comput. Geosci., 32, 12831298, 2006.

Jarvis, A., Rubiano, J. E., Nelson, A., Farrow, A., and Mulligan, M.: Practical use of SRTM data in the tropics: Comparisons with digital elevation models generated from cartographic data, Cali, CO: Centro Internacional de Agricultura Tropical (CIAT), p. 32, Working document no. 198, 2004.

Javelle, P., Demargne, J., Defrance, D., Pansu, J., and Arnaud, P.: Evaluating flash-flood warnings at ungauged locations using post-event surveys: a case study with the AIGA warning system, Hydrolog. Sci. J., 59, 1390-1402, 2014.

Kamali, B., Abbaspour, K. C., and Yang, H.: Assessing the Uncertainty of Multiple Input Datasets in the Pre- diction of Water Resource Components, Water, 9, 709, https://doi.org/10.3390/w9090709, 2017.

Kumar, S. and Merwade, V.: Impact of watershed subdivision and soil data resolution on SWAT model calibration and parameter uncertainty, J. Am. Water Resour. As., 45, 1179-1196, 2009.

Lagadec, L.-R., Breil, P., Chazelle, B., Braud, I., and Moulin, L.: Use of post-event surveys of impacts on railways for the evaluation of the IRIP method for surface runoff mapping, in: E3S Web of Conferences, vol. 7, p. 10005, EDP Sciences, 2016.

Laurantin, O.: ANTILOPE: Hourly rainfall analysis merging radar and rain gauge data, in: Proceedings of the International Symposium on Weather Radar and Hydrology, Grenoble, France, 10-12 March 2008, 2-8, 2008.

Lee, Y. and Singh, V.: Application of the Kalman filter to the Nash model, Hydrol. Process., 12, 755-767, 1998.

Liu, Y., Weerts, A. H., Clark, M., Hendricks Franssen, H.-J., Kumar, S., Moradkhani, H., Seo, D.-J., Schwanenberg, D., Smith, P., van Dijk, A. I. J. M., van Velzen, N., He, M., Lee, H., Noh, S. J., Rakovec, O., and Restrepo, P.: Advancing data assimilation in operational hydrologic forecasting: progresses, challenges, and emerging opportunities, Hydrol. Earth Syst. Sci., 16, 3863-3887, https://doi.org/10.5194/hess-16-3863-2012, 2012.

Maidment, D. R.: Handbook of hydrology, vol. 1, McGraw-Hill, New York, 1993.

Marchi, L., Borga, M., Preciso, E., and Gaume, E.: Characterisation of selected extreme flash floods in Europe and implications for flood risk management, J. Hydrol., 394, 118-133, 2010.

Masson, V., Champeaux, J.-L., Chauvin, F., Meriguet, C., and Lacaze, R.: A global database of land surface parameters at 1-km resolution in meteorological and climate models, J. Climate, 16, 1261-1282, 2003.

McBride, J. L. and Ebert, E. E.: Verification of quantitative precipitation forecasts from operational numerical weather prediction models over Australia, Weather Forecast., 15, 103-121, 2000.

Nachtergaele, F., van Velthuizen, H., Verelst, L., Wiberg, D., Batjes, N., Dijkshoorn, K., van Engelen, V., Fischer, G., Jones, A., and Montanarela, L.: The harmonized world soil database. Version 1.2, in: Harmonized World Soil Database (version 1.2). FAO, Rome, Italy and IIASA, Laxenburg, Austria, 2012.

Nash, J. E. and Sutcliffe, J. V.: River flow forecasting through conceptual models part I - A discussion of principles, J. Hydrol., 10, 282-290, 1970.

Noilhan, J. and Planton, S.: A simple parameterization of land surface processes for meteorological models, Mon. Weather Rev., 117, 536-549, 1989.

Nuissier, O., Marsigli, C., Vincendon, B., Hally, A., Bouttier, F., Montani, A., and Paccagnella, T.: Evaluation of two convectionpermitting ensemble systems in the HyMeX Special Observation Period (SOP1) framework, Q. J. Roy. Meteor. Soc., 142, 404418, 2016.

Payrastre, O., Lebouc, L., Ayral, P. A., Brunet, P., Delrieu, G., Douvinet, J., Dramais, G., Javelle, P., Johannet, A., Adamovic, M., Adnes, C., Cantet, P., Chapuis, M., Coutouis, A., Creutin, J.-D., Gonzalez-Sosa, E., Ruin, I., Saint-Martin, C., Shabou, S., and Whilhelm, B.: The October 2015 flash-floods in south eastern France: first discharge estimations and comparison with other flash-floods documented in the framework of the Hymex project, in: EGU General Assembly Conference Abstracts, vol. 18, p. 13912, 2016. 
Payrastre, O., Ayral, P.-A., Barachet, C., Borell, V., Boudevillain, B., Bouvier, C., Brunet, P., Cantet, P., Coussot, C., Delrieu, G., Despax, A., Didon-Lescot, J.-F., Domergue, M., Ecrepont, S., Froidurot, S., Grard, N., Lagadec, L.-R., Le Bihan, G., Le Boursicaud, R., Mansanarez, V., Marchand, P., Martin, P., Mosini, M.-L., Mosset, A., Navas, R., Neppel, L., Perez, S., Raynaud, F., Saint-Martin, C., and Wijbrans, A.: Hydrological post event survey after the autumn 2014 floods in the Cévennes region in France: results and first hydrological analyses, in: 9th HyMeX workshop, 21-25 September 2015, Mykonos, Greece, 2015.

Pellarin, T., Delrieu, G., Saulnier, G.-M., Andrieu, H., Vignal, B., and Creutin, J.-D.: Hydrologic visibility of weather radar systems operating in mountainous regions: Case study for the Ardeche catchment (France), J. Hydrometeorol., 3, 539-555, 2002.

Piotte, O., Boura, C., Cazaubon, A., Chaléon, C., Chambon, D., Guillevic, G., Pasquet, F., Perherin, C., and Raimbault, E.: Collection, storage and management of high-water marks data: praxis and recommendations, in: E3S Web of Conferences, vol. 7, p. 16003, EDP Sciences, 2016.

Ricard, D., Ducrocq, V., and Auger, L.: A climatology of the mesoscale environment associated with heavily precipitating events over a northwestern Mediterranean area, J. Appl. Meteorol. Clim., 51, 468-488, 2012.

Roux, H., Labat, D., Garambois, P.-A., Maubourguet, M.-M., Chorda, J., and Dartus, D.: A physically-based parsimonious hydrological model for flash floods in Mediterranean catchments, Nat. Hazards Earth Syst. Sci., 11, 2567-2582, https://doi.org/10.5194/nhess-11-2567-2011, 2011.

Rozalis, S., Morin, E., Yair, Y., and Price, C.: Flash flood prediction using an uncalibrated hydrological model and radar rainfall data in a Mediterranean watershed under changing hydrological conditions, J. Hydrol., 394, 245-255, 2010.

Saint-Martin, C., Javelle, P., and Vinet, F.: DamaGIS: a multisource geodatabase for collection of flood-related damage data, Earth Syst. Sci. Data, 10, 1019-1029, https://doi.org/10.5194/essd-101019-2018, 2018.

Savenije, H. H. G.: HESS Opinions "Topography driven conceptual modelling (FLEX-Topo)”, Hydrol. Earth Syst. Sci., 14, 26812692, https://doi.org/10.5194/hess-14-2681-2010, 2010.

Schaake, J. C., Hamill, T. M., Buizza, R., and Clark, M.: HEPEX: the hydrological ensemble prediction experiment, B. Am. Meteorol. Soc., 88, 1541-1547, 2007.
SCS: SCS National Engineering Handbook Soil Conservation Service, US Department of Agriculture, Washington D.C., 1964.

Sharifi, A. and Kalin, L.: Effect of land use uncertainty on watershed modeling, in: World Environmental and Water Resources Congress 2010: Challenges of Change, 4730-4739, 2010.

Silvestro, F. and Rebora, N.: Impact of precipitation forecast uncertainties and initial soil moisture conditions on a probabilistic flood forecasting chain, J. Hydrology, 519, 1052-1067, 2014.

Tubiello, F. N., Biancalani, R., Salvatore, M., Rossi, S., and Conchedda, G.: A worldwide assessment of greenhouse gas emissions from drained organic soils, Sustainability, 8, 371, https://doi.org/10.3390/su8040371, 2016.

Van Steenbergen, N. and Willems, P.: Rainfall uncertainty in flood forecasting: Belgian case study of Rivierbeek, J. Hydrol. Eng., 19, 05014013, https://doi.org/10.1061/(ASCE)HE.19435584.0001004, 2014.

Vázquez, R., Feyen, L., Feyen, J., and Refsgaard, J.: Effect of grid size on effective parameters and model performance of the MIKE-SHE code, Hydrol. Process., 16, 355-372, 2002.

Vincendon, B., Ducrocq, V., Nuissier, O., and Vié, B.: Perturbation of convection-permitting NWP forecasts for flash-flood ensemble forecasting, Nat. Hazards Earth Syst. Sci., 11, 1529-1544, https://doi.org/10.5194/nhess-11-1529-2011, 2011.

Vincendon, B., Édouard, S., Dewaele, H., Ducrocq, V., Lespinas, F., Delrieu, G., and Anquetin, S.: Modeling flash floods in southern France for road management purposes, J. Hydrol., 541, 190-205, 2016.

Vivoni, E. R., Entekhabi, D., and Hoffman, R. N.: Error propagation of radar rainfall nowcasting fields through a fully distributed flood forecasting model, J. Appl. Meteorol. Clim., 46, 932-940, 2007.

Yen, H., Sharifi, A., Kalin, L., Mirhosseini, G., and Arnold, J. G.: Assessment of model predictions and parameter transferability by alternative land use data on watershed modeling, J. Hydrol., 527, 458-470, 2015.

Zalachori, I., Ramos, M.-H., Garçon, R., Mathevet, T., and Gailhard, J.: Statistical processing of forecasts for hydrological ensemble prediction: a comparative study of different bias correction strategies, Adv. Sci. Res., 8, 135-141, 2012.

Zappa, M., Jaun, S., Germann, U., Walser, A., and Fundel, F.: Superposition of three sources of uncertainties in operational flood forecasting chains, Atmos. Res., 100, 246-262, 2011. 